\title{
ASSESSMENT OF GROUNDWATER RESOURCES AFTER GERD IN EGYPT
}

Samah H. Abd El Ghany

Lecturer, $10^{\text {th }}$ of Ramadan Higher Technological Institute, Civil Engineering Department, Ph.D. of Civil Engineering, Irrigation and Hydraulics Department, Ain Shams University, Egypt

\begin{abstract}
Ahmed A. Hassan
Professor of Environmental Hydrology, Faculty of Engineering, Irrigation and Hydraulics Department, Ain Shams University, Egypt
\end{abstract}

\section{Saleh O. K}

Professor of Hydraulics, Faculty of Engineering, Water \& Water Structures Department, Zagazig University, Egypt

\section{Riad Peter H}

Associate Professor, Faculty of Engineering, Irrigation and Hydraulics Department, Ain Shams University, Egypt

\begin{abstract}
Groundwater is a valuable source in Egypt. However, it is expected to face many challenges in next few decades due to climate changes, rapid population increase and development in the upper Nile Basin countries. All of these factors are putting more stresses on this source. Groundwater sector in Egypt is expected to suffer of rapid declination in levels due to the reduction of water recharge in the renewable aquifers (Nile Valley and Delta aquifers). This decline is expected due to climate change (on the long term) and due to GERD reservoir filling and operation stages (on the short term), which will cut large volumes of water which used to reach to Egypt from August to October/November.
\end{abstract}

Moreover, the availability of the water all the year time and turning the flow into controlled instead of natural flow will encourage for more uses of the water in Sudan, which means more shortage in water supply to Egypt. Such decline in surface water source will put more pressure on the renewable and non-renewable aquifers in Egypt. Other concerns, due to decline of surface water, are seawater intrusion and land salinization which will affect the groundwater quality and adversely affect the agricultural activities and production.

This paper is considered as a key reference for who are interested in evaluating the impacts of GERD on groundwater resources in Egypt. This, in turn, can be used as 
a good guide for the stakeholders and decision makers for better management and to help in minimizing the expected negative impacts.

So, Stakeholders and water specialists in Egypt should think in many other alternatives to overcome the challenges in water sector for the next decades. As explained before, traditional water supply is vulnerable to many reasons and nontraditional sources should be well studied and planned. Many alternatives are discussed in this paper.

Keywords: Groundwater, GERD, saltwater intrusion, lands salinization, water management, negative impacts

Cite this Article: Samah H. Abd El Ghany, Ahmed A. Hassan., Saleh O. K. and Riad Peter H., Assessment of Groundwater Resources after GERD in Egypt, International Journal of Civil Engineering and Technology, 11(12), 2020, pp. 16-38. https://iaeme.com/Home/issue/IJCIET?Volume=11\&Issue $=12$

\section{INTRODUCTION TO THE NILE BASIN}

The Nile River is considered as the world's longest river, its total length of $6670 \mathrm{~km}$ with a catchment area of 3.2 million $\mathrm{km}^{2}$. The Nile Basin Countries are eleven countries. The Nile is the main water source of Egypt. The Equatorial Lakes plateau in Uganda is drained by tributaries forming the White Nile, which joins the Blue Nile (originating from the Ethiopian Highlands) at Khartoum in Sudan. River Atbara is another major tributary of the Nile system, which also has its headwater on the Ethiopian plateau and joins the main Nile at Atbara in Sudan, north of Khartoum. Thereafter, the Nile flows through the Saharan Desert without any significant tributaries (Figure 1) (Williams, 2009).

The catchment of the Blue Nile and its tributaries covers approximately $250,000 \mathrm{~km}^{2}$ in the Ethiopian Plateau, and it captures further tributaries of the Sudan which equates 324,000 $\mathrm{km}^{2}$ at its confluence with the White Nile in Khartoum. The Blue Nile is originated in the Ethiopian plateau, which rises at elevations of 2000- $3000 \mathrm{~m}$ above mean sea level (El Bastawesy et. al., 2015).

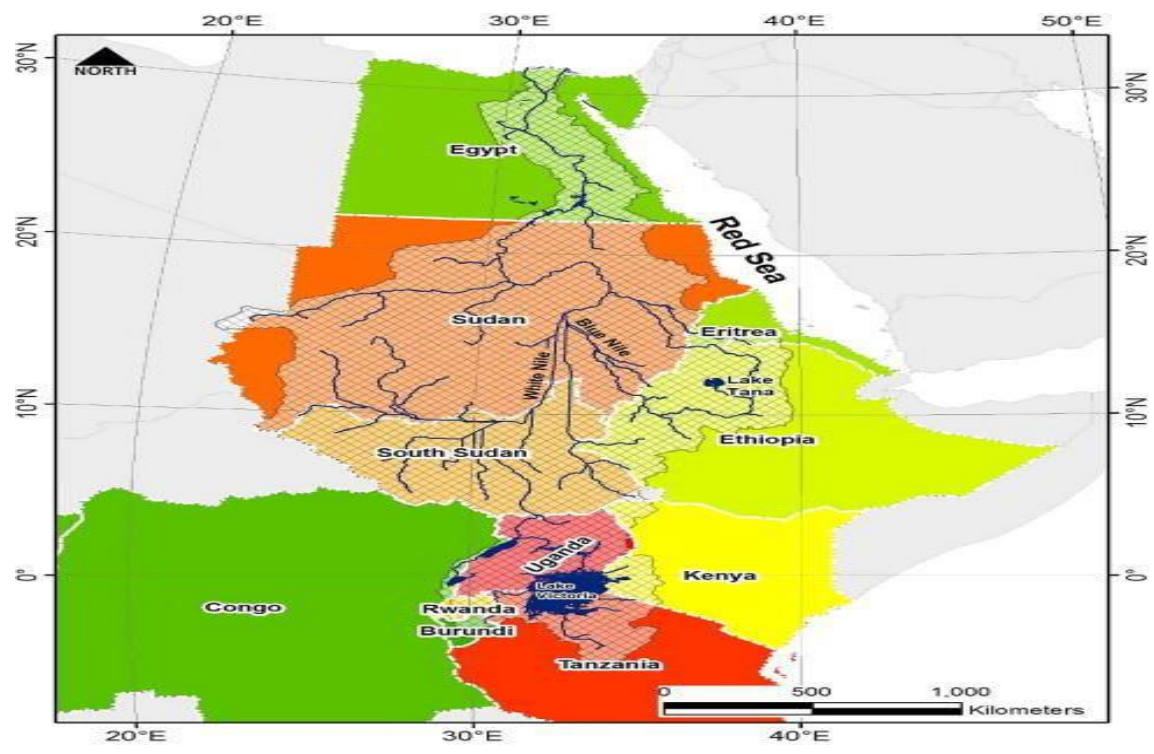

Figure 1 Catchment of the Nile basin; the catchment morphometry is derived from the GTOPO30 data

During the dry years, the water discharge of the Nile River reaches to $44 \mathrm{BCM} / \mathrm{year}$ instead of the average inflow $84 \mathrm{BCM}$ at Nasser Lake. The frequent repetition of droughts in 
the Nile basin within the last 45 years caused in killing millions of people in Sudan, Kenya, Tanzania, and Ethiopia, while no casualties in Egypt due to the existence of the saving bank of water, High Aswan Dam (HAD) which also, protected Egypt during the high flood seasons.

Egypt in North West of Africa, it is in an arid and high temperate area. The climate of Egypt ranges between hyper-arid and arid with average rainfall as low as $20 \mathrm{~mm} / \mathrm{year}$. Thus, the agriculture in Egypt relies primarily and for the most part on irrigation all around the year. From the total water resources of Egypt, there is only 5.5 BCM from deep groundwater and 1.3 BCM from rain, which means that Egypt relies mainly on Nile water.

It is important to study the aquifers systems in downstream countries (Egypt and Sudan) to know their characteristics and their recharge sources, hence the impacts of GERD on them.

\section{GROUNDWATER SYSTEM IN EGYPT}

In arid and semiarid regions, where water scarcity is almost endemic, groundwater plays a key role in meeting domestic and irrigation demands. The amount of abstracted groundwater in Egypt is approximately $7.5 \mathrm{~km}^{3} /$ year. In many cases and locations, groundwater serves as the only reliable source of drinking and irrigation water. Unfortunately, this vital resource is vulnerable to contamination. The age of groundwater may range from a few years or less to tens of thousands of years or even more. Old meteoric water often occurs in arid areas where most of the groundwater existed during previous climatic periods with higher rainfall. In Egypt, as an example, the groundwater age of Suez Rift Valley is more than 31,000 years. In many regions, massive use of groundwater has been practiced for some time for irrigation. Groundwater mining and the lack of adequate planning, legal frameworks, and governance have opened a new debate on the sustainability of the intensive use of groundwater resources (Ashour, et. Al. 2009). The hydrogeology map (Figure 2) shows a simplified version of the type and productivity of the main aquifers at a national scale.

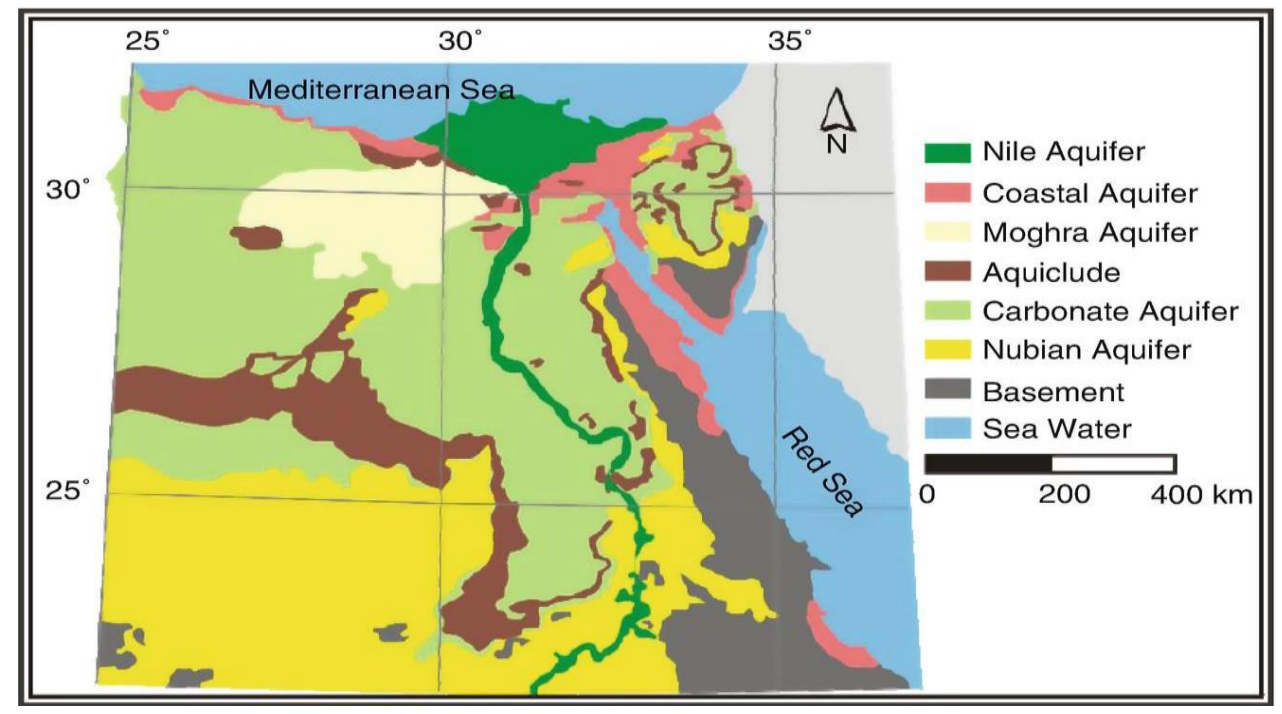

Figure 2 Hydrogeology Map of Egypt (simplified after RIGW 1988, 1993)

The hydrogeological framework of Egypt (Figure 2, Table 1) comprises eight hydrogeological units (RIGW 1988, 1993): (1) Nile Valley and Delta aquifers, (2) Coastal aquifers, (3) Nubian Sandstone aquifer, (4) Moghra aquifer, (5) Tertiary aquifer, (6) Karstified Carbonate rocks complex aquifers, (7) Fissured (fractured rock) basement complex aquifers and (8) Aquiclude rocks. The water-bearing rocks in Egypt are classified into the following two groups: 
(a) Granular water-bearing rocks and (b) Fissured and karstified water-bearing rocks.

Table 1 The main hydrological units in Egypt (RIGW, 1993)

\begin{tabular}{llllll}
\hline Lithology (rock type) & Unit & \multicolumn{2}{l}{ Recharge } & Distribution & Productivity \\
\cline { 3 - 5 } & & Surface & Sub-surface & \\
\hline Granular rocks & (1) Nile Valley and delta & Continuous & Continuous & Extensive & High \\
& (2) Coastal aquifers & Occasional & Limited & Local & Moderate to high \\
& (3) Nubian Sandstone complex & None & Limited & Extensive & Moderate to high \\
& (4) Mohgra aquifer & Insignificant & Locally & Extensive & Low to moderate \\
& (5) Tertiary aquifers & Insignificant & Limited & Local & Low to moderate \\
Karstfied and fissured rocks & (6) Carbonates & None & Locally & Extensive & Moderate \\
& (7) Hard rocks & Insignificant & Limited & Local & Low \\
Clay or shale & Aquicludes & None & None & Generally local & None
\end{tabular}

Table 2 summarizes the characteristics of the main aquifer systems of Egypt. Data are adopted from different sources, mainly, RIGW (1988, 1993), Abu Zeid and Rady (1992), Hefny (1992), Allam et al. (2002).

Table 2 Characteristics of main aquifer system of Egypt (RIGW, 1993)

\begin{tabular}{|c|c|c|c|c|c|c|c|}
\hline Name of aquifer & Type locality & $\begin{array}{l}\text { Depth of top } \\
\text { aquifer (m) }\end{array}$ & $\begin{array}{l}\text { Saturated } \\
\text { thickness (m) }\end{array}$ & $\begin{array}{l}\text { Depth to water } \\
\text { table (m) }\end{array}$ & $\begin{array}{l}\text { Hydraulic } \\
\text { conductivity } \\
\text { (m/day) }\end{array}$ & Porosity (\%) & $\begin{array}{l}\text { Salinity } \\
\text { (ppm) }\end{array}$ \\
\hline \multicolumn{8}{|l|}{ Granular rocks } \\
\hline \multirow[t]{3}{*}{ Nile Valley and Delta aquifer } & Nile Valley & $0-20$ & $10-200$ & $0-5$ & $50-70$ & $25-30$ & $<1,500$ \\
\hline & Nile Delta (south) & $0-20$ & $100-500$ & $0-5$ & $50-100$ & $25-30$ & $<1,500$ \\
\hline & Nile Delta (north) & $20-100$ & $500-1,000$ & $0-2$ & $<50$ & $>30$ & $>5,000$ \\
\hline \multirow[t]{3}{*}{ Coastal aquifers } & Mediterranean & $\mathbf{0}$ & $<5$ & \pm 15 & $15-25$ & $>30$ & $1,000-6,000$ \\
\hline & El-Qaa plain & $50-100$ & $60-80$ & $50-70$ & $5-10$ & & $600-2,500$ \\
\hline & El-Arish aquifer & $15-30$ & $40-50$ & $0-30$ & $5-20$ & & $1,500-6,000$ \\
\hline \multirow[t]{10}{*}{ Nubian Sandstone } & Western Desert & & & & & & \\
\hline & Kharga & $50-200$ & $500-700$ & $0-30$ & $2-4$ & 20 & $<1,000$ \\
\hline & Dakhla & 200 & $500-1,000$ & $0-20$ & $6-7$ & $20-25$ & $<1,000$ \\
\hline & Bahariya & $150-300$ & $1000-1,500$ & $0-20$ & $5-10$ & $20-40$ & $<1,000$ \\
\hline & Farafra & $200-500$ & $1000-2,000$ & Flow & $2-5$ & $20-30$ & $<1,000$ \\
\hline & East Oweinat & $10-20$ & $100-300$ & $20-30$ & $10-20$ & $20-30$ & $<1,000$ \\
\hline & Nile basin fringes & & & & & & \\
\hline & Qena area & $100-250$ & 500 & Flow & $1-2$ & & $2,000-2,500$ \\
\hline & $\begin{array}{l}\text { Laqeita area } \\
\text { Eastern Desert }\end{array}$ & $100-500$ & $200-400$ & Flow & $1-3$ & & $1500-2,000$ \\
\hline & Esh El Mallaha & $0-30$ & $>200$ & Flow & & & $3,000-4,000$ \\
\hline \multirow[t]{3}{*}{ Nubian Sandstone } & Sinai & & & & & & \\
\hline & Nakhla & 1000 & 2,000 & 200 & & & $1,500-2,000$ \\
\hline & Oyun Moussa & $100-500$ & 1,500 & Flow & & & $1,000-4,000$ \\
\hline Mohgra aquifer & Natron/Qattara & $0-200$ & $500-900$ & 100 & & 20 & $1,000-1,2000$ \\
\hline \multicolumn{8}{|l|}{ Fissured rocks } \\
\hline Carbonates & Wadi Araba & $0-100$ & 500 & Flow & & & $1,000-1,2000$ \\
\hline Hard rocks & South Sinai & $0-50$ & & +50 & & & $1,000-2,000$ \\
\hline
\end{tabular}

Depths are measured from ground surface

\subsection{Nubian Sandstone Aquifer}

The Nubian Sandstone aquifer system covers south-east Libya, Egypt, north-east Chad, north Sudan, and western Saudi Arabia with a total area of about two million kilometers. In the north and north-west, the pore volume of sediment is filled with saline water that entered the system either via an intrusion of Mediterranean Sea water from the north or groundwater that was not flushed out since the sedimentation of marine deposits (Thorweihe and Heinl 2002).

This interface between fresh and saline water forms the system's border in the north and north-west and is considered spatially stable in its position although slow movement is 
conceivable (Figure 3). The Nubian Sandstone aquifer system is, therefore, a broadly closed system.

Based on updated subsurface data, the calculated Nubian Sandstone aquifer system groundwater volume is in the order of $150,000 \mathrm{~km}^{3}$, generally equal to the estimation given by Ambroggi, 1966.

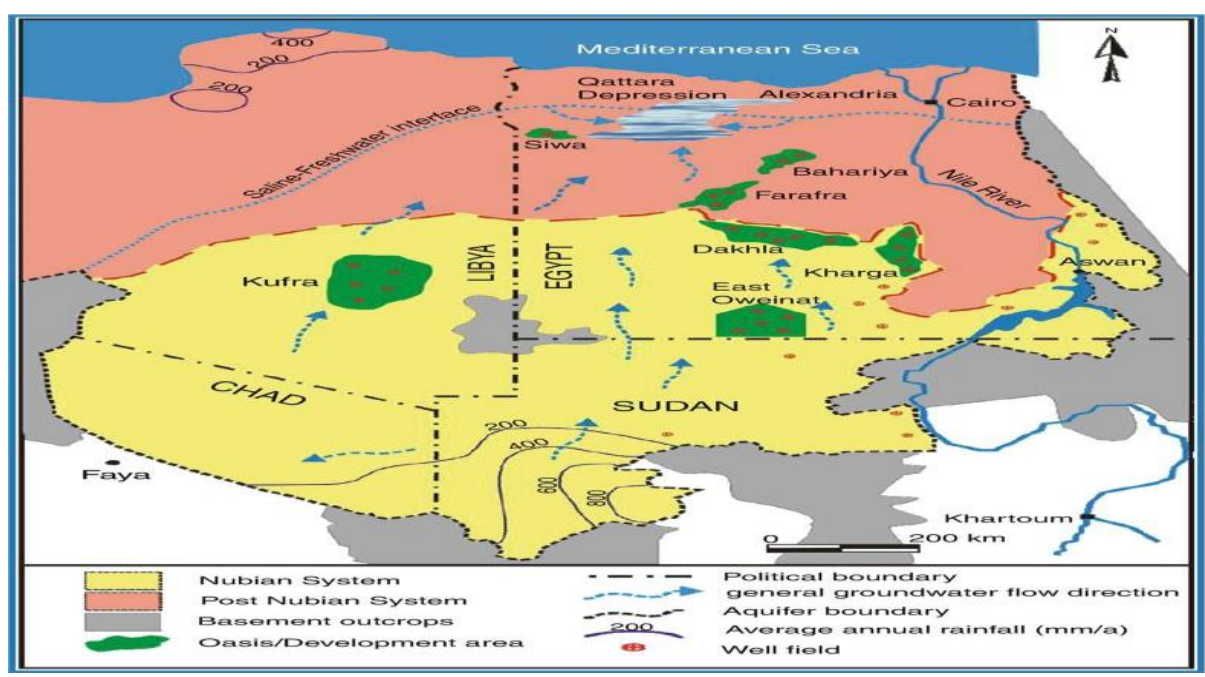

Figure 3 Nubian Sandstone Aquifer System (NSAS) and Groundwater flow (Salem and Pallas 2004)

In Egypt the Nubian Sandstone aquifer is divided into the following subsystems.

\section{Nubian sandstone aquifer at the Western Desert}

The Western Desert Basin is exploited particularly in the New Valley area, where intensive deep drilling was carried out during the past five decades "more than 500 wells have been drilled to depths from 500 to $1,000 \mathrm{~m}^{3}$ (Figure 4). The Nubian Sandstone consists of alternating beds of sandstone and clay. The clay beds are laterally discontinuous and separate. The sandstone is separated into a multi-layered aquifer system, bounded below by impervious basement rocks. The Nubian Sandstone is occasionally overlain by impervious rocks and interbedded by clays. Groundwater flow in the Nubian Sandstone system in the Western Desert is generally towards the northeast with a gradient of the order of $0.5 \mathrm{~m} / \mathrm{km}$.

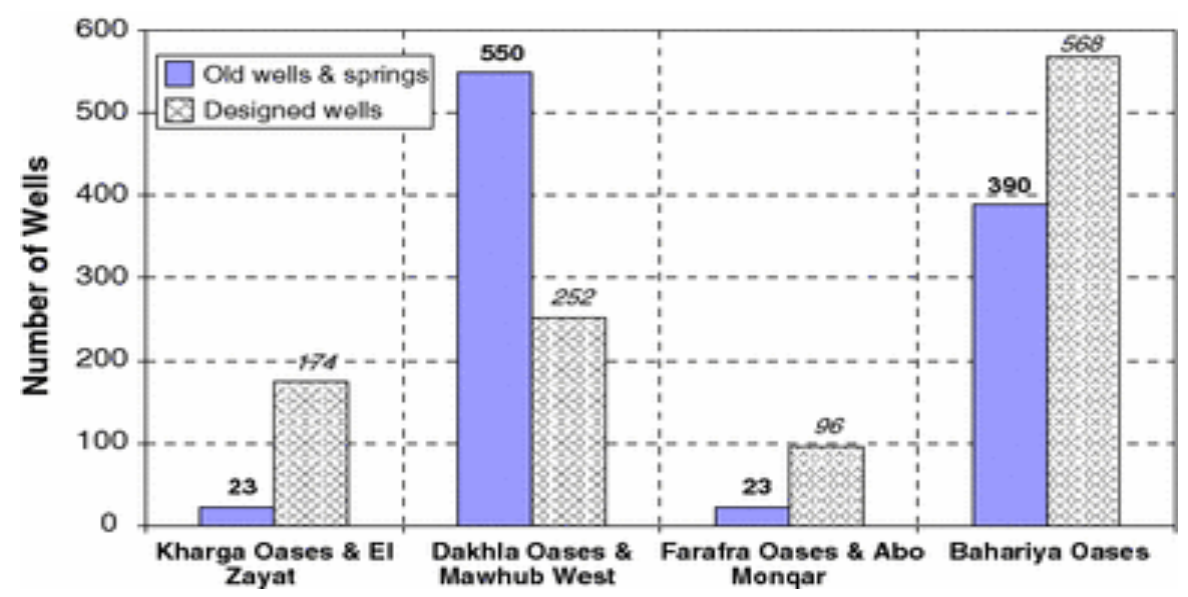

Figure 4 Existing groundwater wells in the Western Desert of Egypt (after El Tahlawi et, al., 2008)

The salinity of the water in the Nubian Sandstone Basin changes horizontally and vertically. The salinity increases down slope of the hydraulic gradient from SW to NE and 
usually decreases with depth. At Kharga and Dakhla (Mut), the salinity decreases from 600 in the upper layers to $200 \mathrm{ppm}$ in the lower layers. Most probably this is due to the long period of exploitation of the shallow aquifers causing an upward movement of the groundwater and eventually due to direct evaporation.

A similar condition is found in the fissured carbonate rocks overlying the Nubian Sandstone complex at Siwa Oasis in the North, where the salinity in the top Miocene layers is over 1,500 ppm and decreases to only $200 \mathrm{ppm}$ in the Cretaceous and Eocene beds.

In the Nubian Sandstone complex, at Siwa Oasis and the Qattara Depression area, a normal salinity zonation is found, where fresh water (about $500 \mathrm{ppm}$ ) is reported above saline water (up to $100,000 \mathrm{ppm}$ ). There are no sharp lines of demarcation between water of different salinities. The regional salinity distribution shows increasing salinities towards the north from fresh water (TDS $<1,000 \mathrm{ppm}$ ) south of latitude $29^{\circ}$ towards highly saline water in the north.

Groundwater investigations east of Oweinat (near to lake Nasser on the border with Sudan) proved the occurrence of two types of water, suitable for irrigation and domestic purposes. TDS ranges between 278 and $824 \mathrm{mg} / \mathrm{l}$. (Werwer et al. 2000).

\section{Nubian sandstone aquifer at the Nile Valley}

This aquifer extends from the north to the south up to Aswan. West of Cairo, groundwater has been found at a depth of one kilometer with high salinity. However, the hydrogeological information about this aquifer is insufficient. Note to mention, the springs of Helwan are mainly connected to this aquifer.

\section{Nubian sandstone aquifer at the Eastern Desert}

It appears in many zones on flowing state, e.g., at El Laqeita area, and east of Qena. The characteristics of this aquifer are different from one place to another. At El Laqeita area a small number of wells penetrate this aquifer, where the groundwater is flowing freely and the piezometric level is up to $112 \mathrm{~m}$ above mean sea level MSL). The salinity varies in the Eastern Desert between 1,000 and 10,000 ppm.

\section{Hydrogeology and sources of recharge in Nubian Sandstone Aquifer in Egypt}

The NSAS in Egypt is assigned to the Paleozoic-Mesozoic ( Klitzsch and Wycisk 1999). It occupies a large area in the Western Desert and parts of the Eastern Desert and Sinai. Groundwater can be found at very shallow depths, where the water bearing formation (horizon) is exposed or at very large depths (up to 1,500 m), where the aquifer is (semi) confined. The deepest water bearing horizons are generally encountered in the north, for example in the Siwa oasis, while the shallowest are encountered in the southern portion in Kharga and the East Oweinat area. The aquifer transmissivity is generally medium to low, varying from 1,000 to $4,000 \mathrm{~m}^{2} /$ day.

Groundwater quality is generally good in the major part, except near the coastal regions and Sinai (Thorweihe and Heinl 2002).

NSAS is a transboundary aquifer which means that the aquifers that traverse a political boundary between two or more sovereign states (an example from the Nubian Sandstone Aquifer System is illustrated in Figure 5), so it is necessary to view the entire aquifer system, including all aquifers that are hydraulically interconnected, directly by lateral or indirectly through vertical contact or through fractures and low permeability formations (aquitards). Groundwater is usually a part of a greater hydrologic system, sometimes with the surface water and/or groundwater of a neighboring country (Eckstein et al. 2005). 


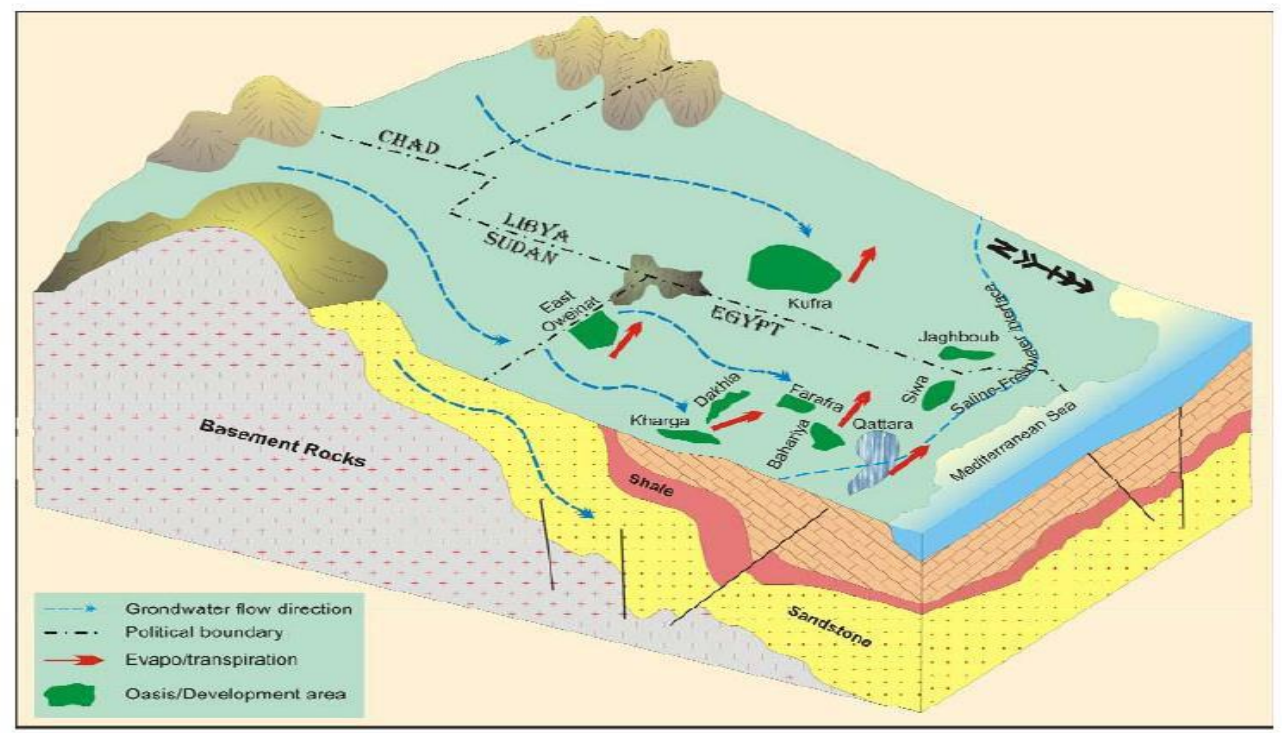

Figure 5 Diagram of the transboundary Nubian Sandstone Aquifer System. Adapted from Salem and Pallas (2004).

Non-renewability is never strictly expressing groundwater resources, but in many cases, especially in the arid regions, the time span required for aquifer replenishment is normally too long in relation to the normal time frame of human activities in general and of water resources planning in particular. In cases where groundwater is available for extraction from the reserves of an aquifer which has a very low current rate of average annual recharge but a large storage capacity, this groundwater resource can thus be termed "nonrenewable". The NSAS (Figure 6) is typically one of these cases, as the development of its reserves involves the mining of its "fossil groundwater". Fossil groundwater is the water that infiltrated usually 10,000 years ago and often under climatic conditions different from the present and that has been stored underground since that time (Margat et al. 2006).

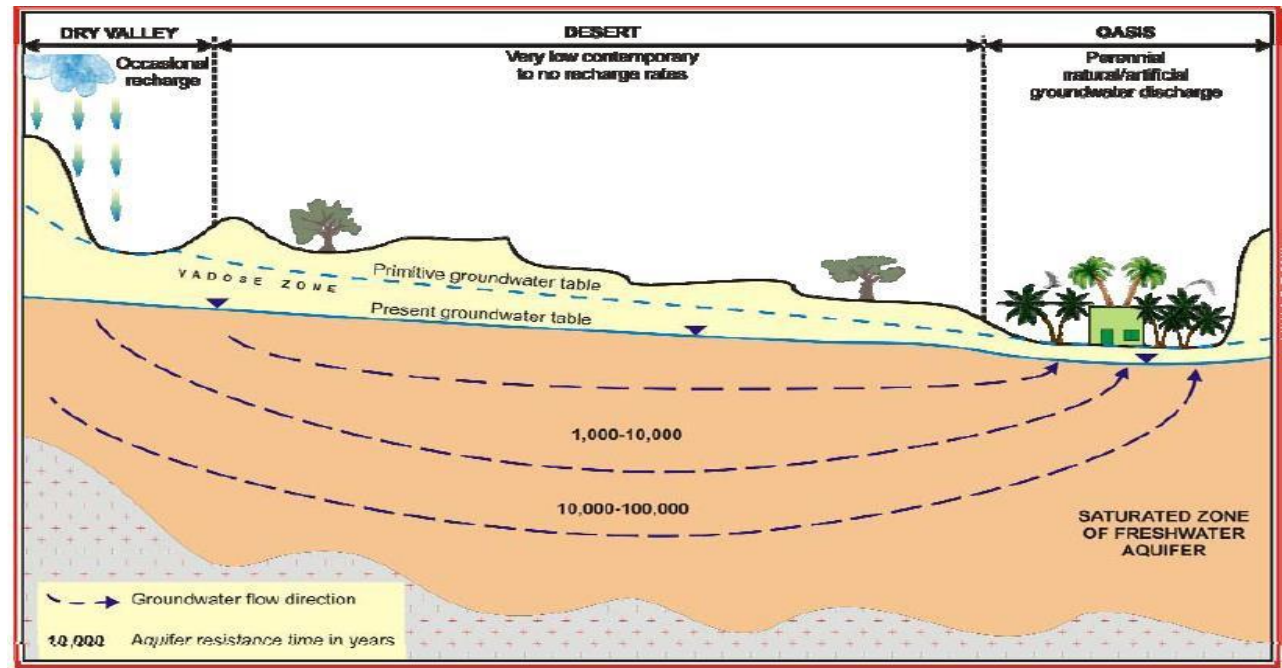

Figure 6 Concept of the non-renewability of the Nubian Sandstone Aquifer System. Typically, recharge area, transmission area and discharge area. Modified after Margat et al. (2006)

\section{Recharge}


NSAS is classified as non-renewable aquifer. However, the transient theory of the groundwater origin did not deny completely the possibility of the recharge from the south but disbelieved the quantity or significance of the kind of recharge for the Nubian Sandstone Aquifer System (Thorweihe and Heinl 2002). However, three possible ways of groundwater recharge for the aquifer system are claimed as follow (Ambroggi, 1966):

- Nile water seepage.

- Regional groundwater influx from areas with modern groundwater recharge.

- Local infiltration through precipitation during wet periods in the past.

\section{GERD DAM}

In the early twentieth century, engineering proposals for the regulation of Lake Tana, at the headwaters of the Blue Nile, were investigated (Garstin, 1904), and several subsequent studies have focused on the feasibility of regulating its outflow. These proposals suggested two possible reservoir sites along the Blue Nile; however, there were some difficulties due to the fact that the Blue Nile flows through deep valleys. Hurst et al. 1951 suggested constructing high dams on the Blue Nile with small capacities. Garstin 1904 highlighted a concern about the huge volumes of sediment carried by the Blue Nile. The US Bureau of Reclamation (1964) prepared a detailed study of the Blue Nile region, including its hydrology, water quality, geology, physiography, mineral resources, sedimentation, land use, groundwater, and local economy. In addition, some irrigation and hydroelectric projects were recommended.

The US Bureau of Reclamation concluded that there are approximately no lands along the Blue Nile which can be irrigated between Lake Tana and the Sudanese- Ethiopian borders. Four dams for the hydroelectric projects were proposed for the Blue Nile downstream of Lake Tana, namely, Karadobi, Mabil, Mendaia, and the Border Project. The Border Project GERD is a hydropower project being built on the Blue Nile to generate $5,150 \mathrm{MWh}$ of electricity and estimated production of 15,692 GWh per year by exploiting the river's streamflow which has an average of $1,541 \mathrm{~m}^{3} / \mathrm{s}$ of annual water discharge. The dam is a roller compacted and reinforced structures $1,780 \mathrm{~m}$ long and $155 \mathrm{~m}$ high. It has two power stations installed at the foot of the dam. The dam is designed to create a reservoir that has a holding capacity of about 74 billion cubic meters (BCM) of water at the full supply level (Figures 9 and 10). There is a rockfill saddle dam with a height of $50 \mathrm{~m}$ was constructed on the west to raise up the reservoir capacity up to 74 BCM (Table 3 ). Figure 12 shows GERD and the saddle dam locations on a topographic map for the project. The idea of constructing the GERD arose after 2009 (Bakheit, 2013; Hammond, 2013; CGE, 2013).

\subsection{GERD main Specifications}

- Dam crest level $=655 \mathrm{~m}$

- Max. Water level $=640 \mathrm{~m}$

- $\quad$ Dam base level = 500 m.a.s.1

- $\quad$ Turbines level $=507$ m.a.s. 1

- Minimum operating levels for 11 upgraded turbines (400 MW) at level 590 m.a.s.l. while $565 \mathrm{~m}$ for ungraded 2 turbines (375 MW).

- The first-year storage 4.9 BCM (within days to weeks in rainy season) to reach the minimum operating level (565 m.a.s.l.). 
Samah H. Abd El Ghany, Ahmed A. Hassan., Saleh O. K. and Riad Peter H.

- Recently, it was noticed from satellite images in 2020 that number of turbines penstocks became 13 only for the upgraded turbines instead of 16 turbines (Figure 7). This will save about 210 Million USD.

- Operating head range for upgraded turbines $=83$ to $133 \mathrm{~m}$.

- There are 2 bottom outlets at level 542 m.a.s.l for diverting water to Sudan and Egypt.

- Average annual inflow $=48.8 \mathrm{BCM}$ (Figure 8)

- Expected evaporation losses $=3 \%$ (approx. 1.5 BCM)

- The two early power generating units probably will be the only units in operation for several years as the filling of the reservoir will take 7 years as pronounced by Ethiopia recently (Tables 4, 5 and Figure 11).

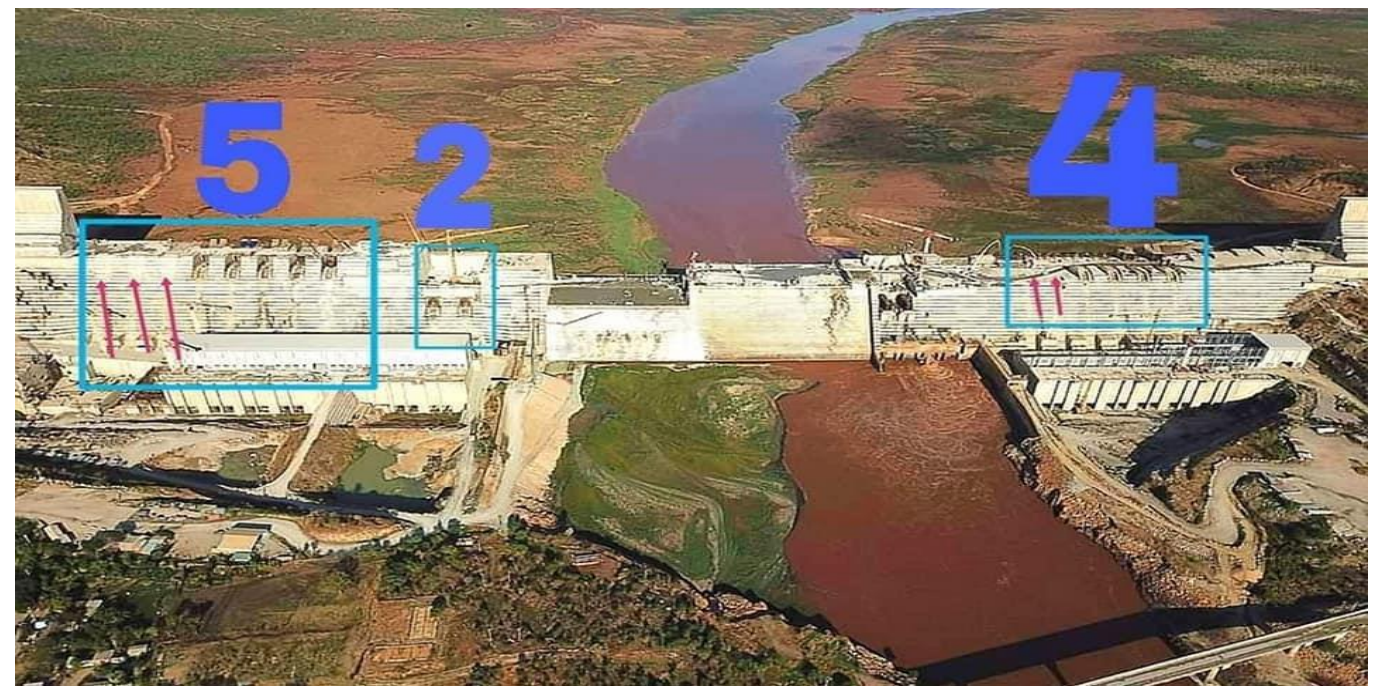

Figure 7 A recent satellite image for GERD

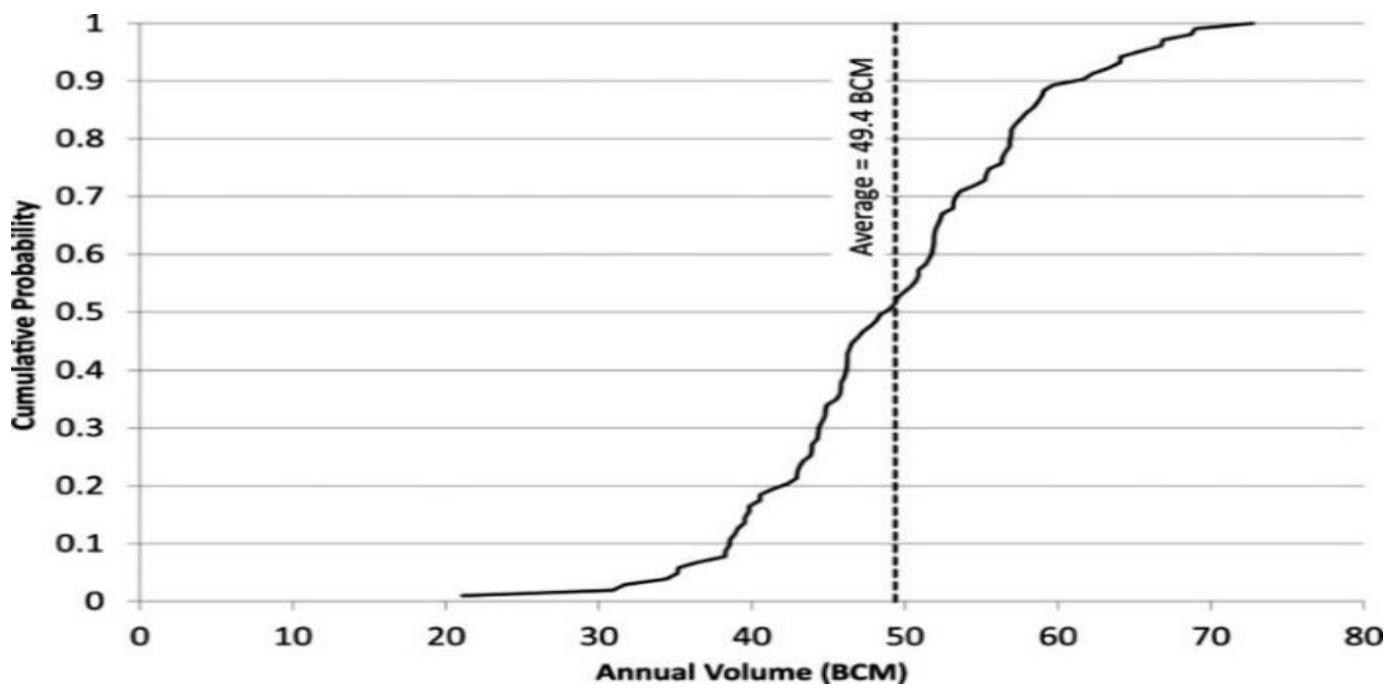

Figure 8 Annual flow volume at the Grand Ethiopian Renaissance Dam (after Kevin et. al, 2016) 


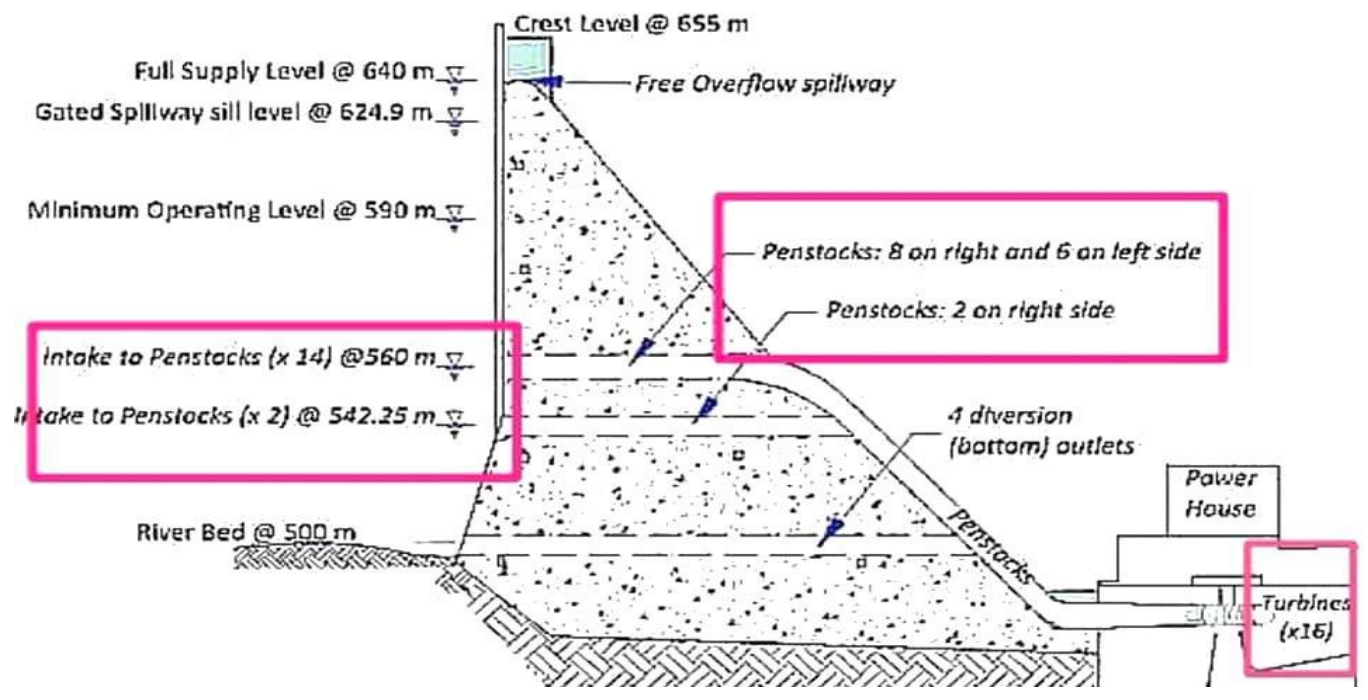

Figure 9 Cross section in GERD

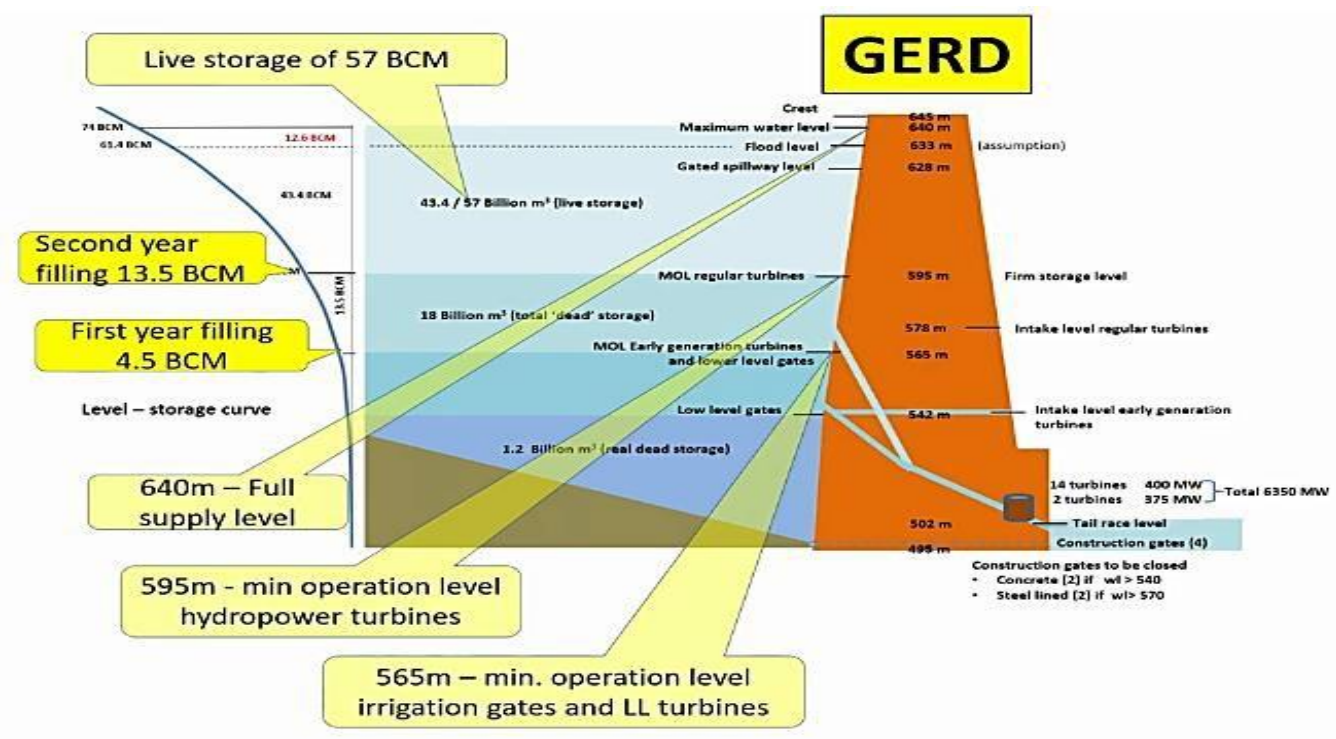

Figure 10 GERD cross section and its volume-elevation curve

Table 3 GERD Saddle Dam features (Abtew and Dessu, 2019)

\begin{tabular}{l|l}
\hline Saddle dam (Salini) & $50 \mathrm{~m}$ \\
\hline Dam height & $5 \mathrm{~km}$ \\
\hline Length & $645 \mathrm{~m}$ asl \\
\hline Crown elevation & Sill elevation $642 \mathrm{~m}$ asl \\
\hline Emergency spillway (ungated) & 16.5 million $\mathrm{m}^{3}$ \\
\hline Dam body volume &
\end{tabular}


Samah H. Abd El Ghany, Ahmed A. Hassan., Saleh O. K. and Riad Peter H.

Table 4 Reservoir water surface elevation, area and volume relationship as derived from $30 \mathrm{~m}$ DEM (Abtew and Dessu, 2019)

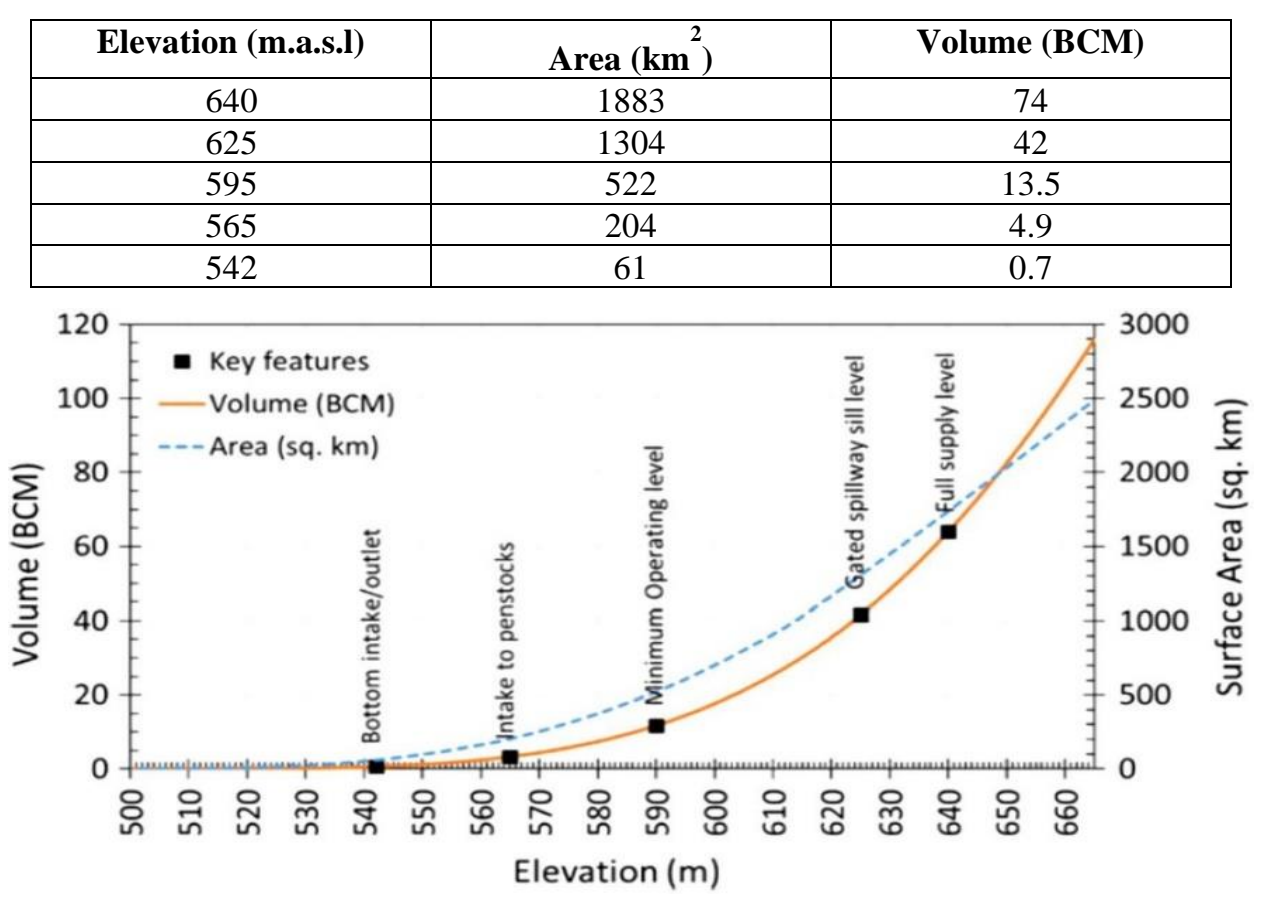

Figure 11 GERD reservoir elevation-area-volume curve (Abtew and Dessu, 2019)

Table 5 Stage based filling plans by NISRG (National Independent Scientific Research Group)

\begin{tabular}{|c|c|c|c|}
\hline Target stage in GERD (M) & $\begin{array}{c}\text { Incremental retained } \\
\text { water at the end of } \\
\text { June (BCM) }\end{array}$ & $\begin{array}{c}\text { Cumulative retained } \\
\text { water at the end of June } \\
\text { (BCM) }\end{array}$ & $\begin{array}{c}\text { Range of possibility of } \\
\text { release based on } \\
\text { hydrology year } \\
\text { (BCM) }\end{array}$ \\
\hline 565 & 4.9 & 4.9 & $37-52$ \\
\hline 595 & 13.5 & 18.4 & $31-43$ \\
\hline 608 & 10.5 & 28.9 & $31-45$ \\
\hline 617 & 10.4 & 39.3 & $31-46$ \\
\hline 625 & 10 & 49.3 & $31-47$ \\
\hline 632 & 11.3 & 60.6 & $31-45$ \\
\hline 640 & \multicolumn{2}{|c|}{ The fully supply level of GERD, with 74 BCM storage capacity } \\
\hline
\end{tabular}

Possible Range of Release $31-43 \mathrm{BCM}$ at $80 \%$ probability, it is to be noted that the recorded historical minimum flow at GERD site is 21 BCM in 1913 and 29 BCM in 1984

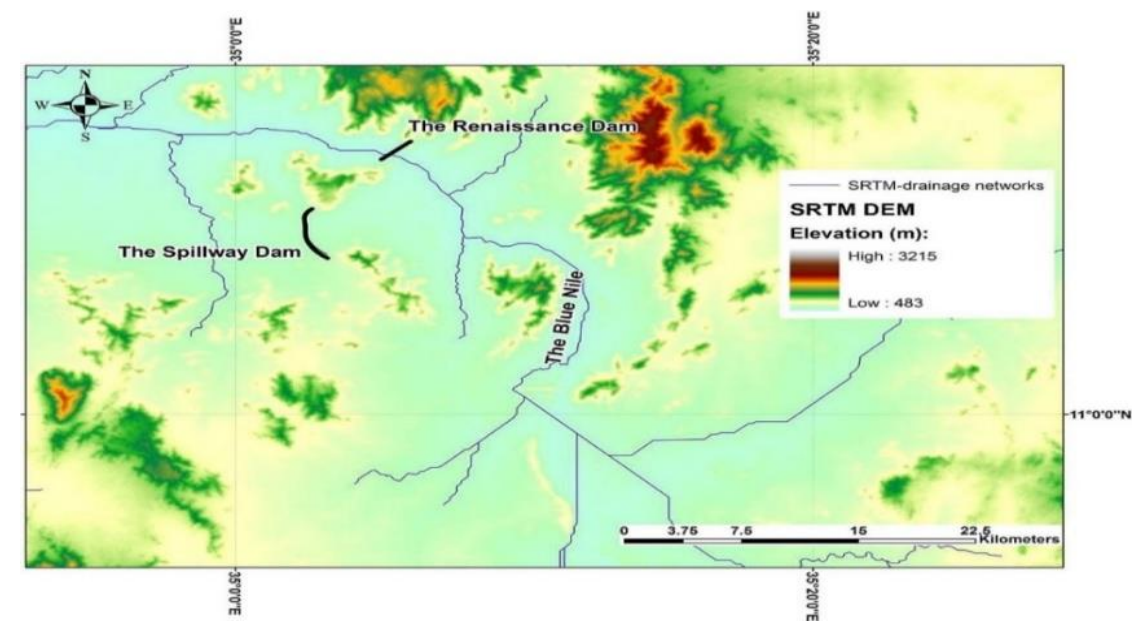

Figure 12 Topography map for GERD and the saddle dam locations 


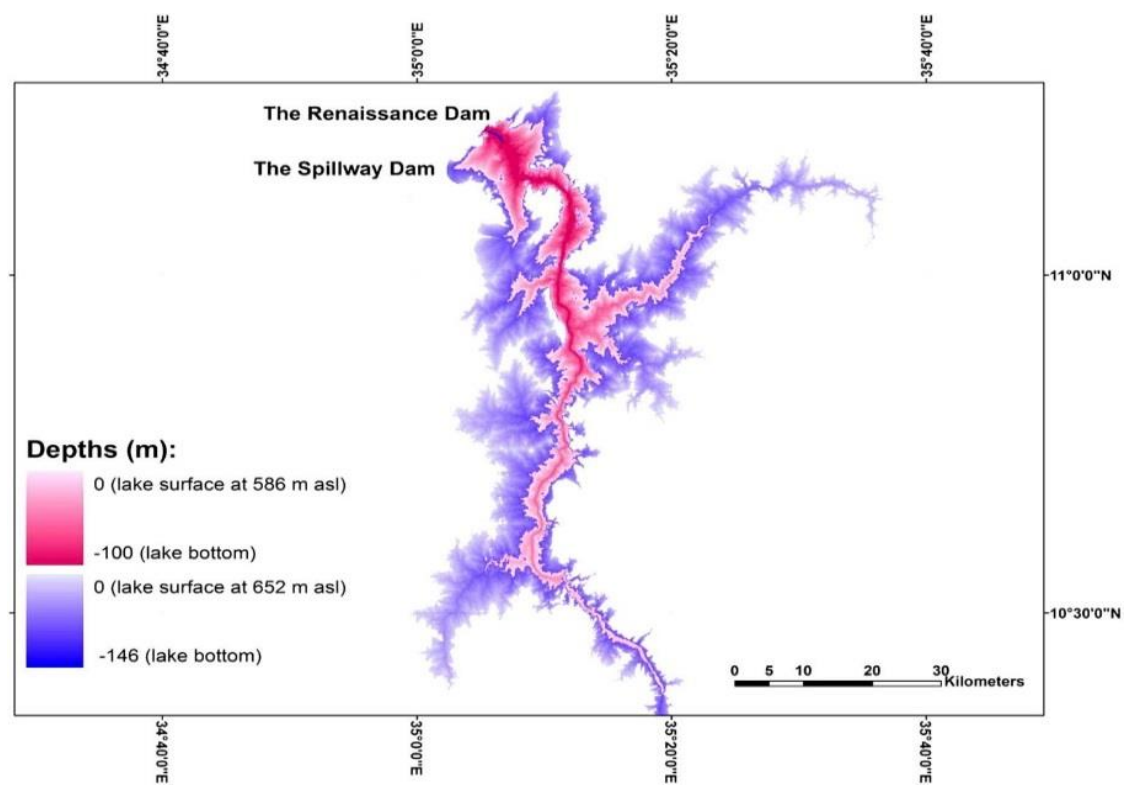

Figure 13 Renaissance Dam lake extensions at levels 586 and 652 m.a.s.l (after El-Bastawesy et. al., 2015)

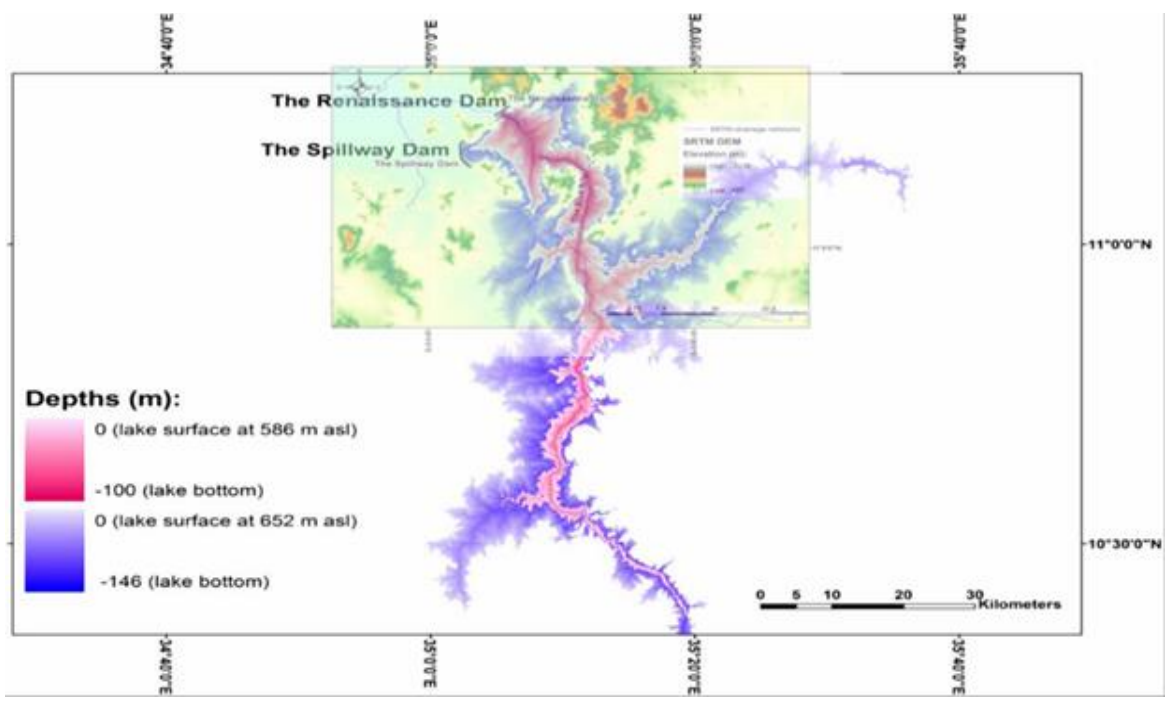

Figure 14 An overlay for the topographic map and GERD Lake

Figures (12\&13\&14) showing Topography map for GERD and the saddle dam locations, Renaissance Dam lake in addition to An overlay for the topographic map and GERD Lake.

\section{IMPACTS OF GERD ON EGYPT}

Few studies have highlighted the impacts of constructing GERD. For example, Chen and Swain, 2014 evaluated strategic priorities, sustainability standards according to the World Commission on Dams (WCD) framework, and geopolitical significance, concluding that project planning has largely ignored the WCD's guidelines and offered limited transparency. Gebreluel, 2014 mentioned that constructing such a dam would provide Ethiopia the capacity to disturb the water flows of the world's largest river in a significant manner. Taye et al., 2016 concluded that the region is encouraged to share data and information with respect to hydrosolidarity principles, which encourages equitable and reasonable utilization of international watercourses.

Mohamed and Elmahdy, 2017 showed that the major faults crosscut the norther and southwestern hills and are parallel with the faults that crosscut the GERD site, and their 
displacement directions are perpendicular to the GERD walls, creating alarm. Furthermore, studies on the hydrological, environmental, and social impact of the dam on the area and the communities are mandatory.

In addition to the Ethiopian hydropower benefits, supporters of the dam claim that increased control over the natural flow regime will result in reduction of the flooding risk to Sudan, reduction of sediment in the river (which currently challenges the management of reservoirs and agricultural schemes), hydropower efficiency benefits for Sudanese reservoirs, improved depth for navigation and reduced pumping costs for water users (Ethiopian NPoE, 2013).

Critics of the dam claim that there are risks of reduced downstream water availability and reduced Egyptian hydropower, the likely loss of recession agriculture in Sudan, losses to the brick production industry that uses the sediment deposits, reduced land fertility due to the reduction of nutrient-rich sediment, and unknown environmental impacts (Beyene, 2013; Egyptian Chronicles, 2013). Although these critics claim the reservoir's planned storage and turbine capacity are oversized, the Ethiopian government believes the benefits will be worth the USD 4.8 billion construction cost. Independent assessments note both potential costs and benefits and have called for more studies to be conducted (Bates et al., 2013; MIT, 2014). While Ethiopia seeks to take greater advantage of the benefits the river may provide, it is still unclear how these benefits and costs may be incurred, especially during the reservoir filling period.

\subsection{GERD Impacts on Groundwater Resources in Egypt}

Several studies have reported that the construction of the Grand Ethiopian Renaissance Dam (GERD) could have severe effects on the water resources in downstream countries, especially Egypt. These effects include changes in surface water level, groundwater levels in shallow and deep aquifers, saltwater intrusion, and increases in soil salinity, which could affect crop yields.

A study made by Farrag, 2005 concluded that there is a strong relationship between groundwater levels (GWL) and surface water levels (SWL) by analyzing both measured and collected data. This means that the problem of surface water shortages due to the construction of the Grand Ethiopian Renaissance Dam (GERD) can affect both surface and groundwater. Wheeler et. al., 2016 deduced that Aswan High Dam (AHD) might reach its minimum operational level during four consecutive dry years, which in turn will affect the water supply toEgypt.

Aziz et. al., 2019 selected a pilot area in the east of the Nile Delta for the assessment. The results of the study showed that GWL is directly proportional to SWL. Comparing the case study of 2012, when SWL was reduced by 50\%, the GWL decreased from $5.0 \mathrm{~m}$ to $2.0 \mathrm{~m}$. After adjustment, the crop patterns from rice to other crops decreased the GWL to $1.30 \mathrm{~m}$.

The study in Abd-Elhamid, 2019 showed that filling the GERD reservoir in three and six years required reducing the groundwater extraction rates from the Nile Delta aquifer by $60 \%$ and $40 \%$, respectively, to maintain the freshwater body in the Nile Delta aquifer; this study developed a numerical model using SEAWAT to simulate the groundwater flow and solute transport while operating the dam.

Shortages in the GWL related to shortages in the SWL should be carefully estimated, as the GWL in the shallow aquifer is a basic alternative to the shortage of SW in many regions in the study area. 


\subsection{Reduction in the Water Share of Egypt}

It is believed that the construction of GERD will affect Egypt's water quota through decreased discharge from the Aswan High Dam (AHD). The main adverse impact in Egypt will be a reduction in power generated at the AHD due to a fall in water levels of Lake Nasser. Based on Ramadan et al. (2015) and Mulat \& Moges (2014), the GERD construction will decrease the active storage of AHD, as in the case of 6 years of filling; yearly outflows of the GERD through the impounding period will be around 29 BCM per year, which represents about $58 \%$ of the mean flow. This in turn will lead to a decrease in the outflow from AHD to the Nile River and the Nile Delta irrigation canals network.

Furthermore, the AHD will reach the minimum operational level during 4 consecutive years in the case the first filling of the GERD occurs during dry years, which would significantly affect the water supply to Egypt (Abdelhaleem and Helal, 2015). Other studies have estimated the impacts of GERD filling years on Blue Nile flow like Keith et. al. 2014 and Abdelhaleem and Helal, 2015 estimated that there will a cut in the Nile flow to Egypt by 25 to $12 \%$, if the reservoir filling takes 3 to 7 years (Table 6).

Table 6 Estimated impacts of GERD filling years on Blue Nile flow (Keith et al. 2014)

\begin{tabular}{|c|c|c|}
\hline $\begin{array}{c}\text { GERD fill rate (\% of } \\
\text { Full supply dam volume) }\end{array}$ & Years to fill & $\begin{array}{c}\text { Estimated } \\
\text { Reduction in Blue Nile } \\
\text { Flow }\end{array}$ \\
\hline 5 & 20 & -4.22 \\
\hline 10 & 10 & -8.77 \\
\hline 15 & 7 & -13.15 \\
\hline 20 & 5 & -16.18 \\
\hline 25 & 4 & -20.72 \\
\hline
\end{tabular}

\subsection{Increase in Seawater Intrusion}

Mohamed and Elmahdy, 2017 used Shuttle Radar Topographic Mission (SRTM) DEM and Advanced Land Observation Satellites to study GERD impacts on water resources. Three scenarios of seawater intrusion along the Egyptian Nile Delta were studied as a result of GERD construction and groundwater table depletion, which is a common contamination problem in the coastal aquifer.

The results showed that the Nile Delta (which is part of the coastal aquifer) demonstrates the vulnerability that is likely to increase due to groundwater table depletion and seawater intrusion, as well as soil salinization. In turn, soil salinization will increase the probability of earth subsidence, geotechnical engineering problems, and agricultural degradation. The results obtained reveal that areas of about 2,677 and $4,675 \mathrm{~km}^{2}$ will experience seawater intrusion when the groundwater table depletes, respectively, by 2 and $5 \mathrm{~m}$ below sea level, which means that one-third of the Nile Delta will experience seawater intrusions when the groundwater table depletes $5 \mathrm{~m}$ below sea level (Figure 15).

The depletion in the groundwater level of the Nile Delta will, of course, lead to soil salinization and seawater intrusion, in turn resulting in earth subsidence and building collapses, especially in coastal Governorates like Alexandria, Beheira and Kafr el-Sheikh. 
Samah H. Abd El Ghany, Ahmed A. Hassan., Saleh O. K. and Riad Peter H.

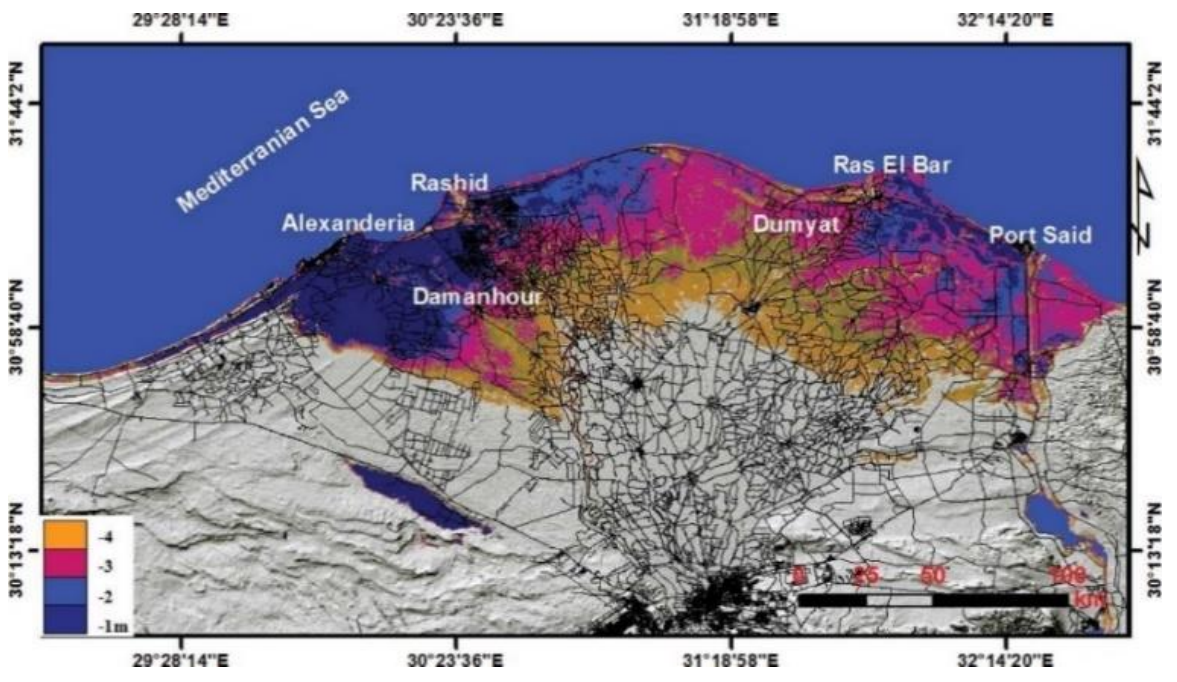

Figure 15 Geohazard map showing the areas of the Nile Delta, Egypt that will be affected by seawater intrusion due to groundwater depletion

Increase in seawater intrusion in coastal aquifers in the North Delta has been threatening groundwater quality and increased salinity in these reservoirs. Abd-Elhamid et. al., 2019 investigated the possible adverse impact of reducing the flow in the Nile River due to the construction of the Grand Ethiopian Renaissance Dam on the Nile Delta aquifer. A numerical model has been developed using SEAWAT to simulate the groundwater flow and solute transport considering the operation of the new dam (Figure 16). Two scenarios of filling the reservoir during 3 and 6 years were considered. The maximum groundwater drawdown in the middle Delta reached to $2.65 \mathrm{~m}$ under the conditions of scenario one and $1.4 \mathrm{~m}$ under the conditions of scenario two. Equi-concentration lines 1000 and 35,000 ppm advanced to a distance of 110.2 and $70.85 \mathrm{~km}$, respectively (Figure 17), under the first scenario and 108.25 and $67.3 \mathrm{~km}$, respectively, under the second scenario. Results indicated that filling the reservoir in 3 and 6 years would require reducing groundwater abstraction rates from the Nile Delta aquifer by 60 and $40 \%$, respectively, to maintain the freshwater body in the Nile Delta aquifer as shown in. (Figure 18 and Figure 19)

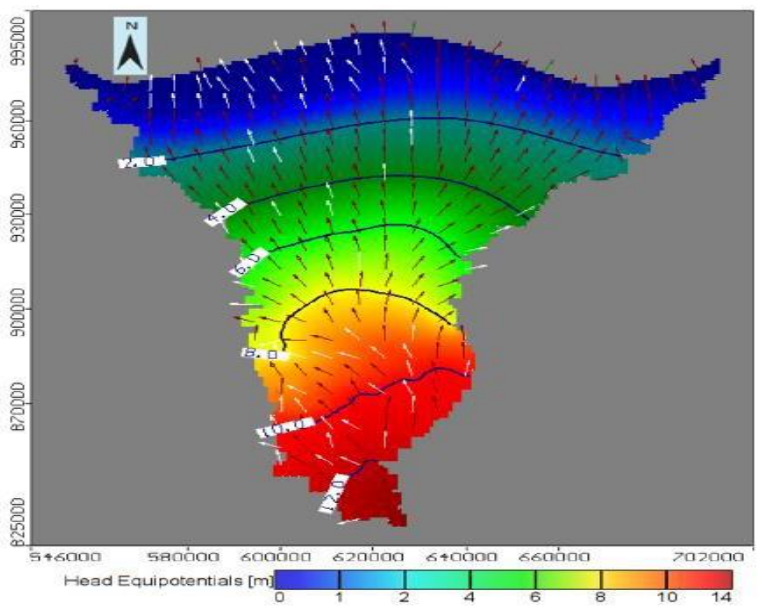

(a)

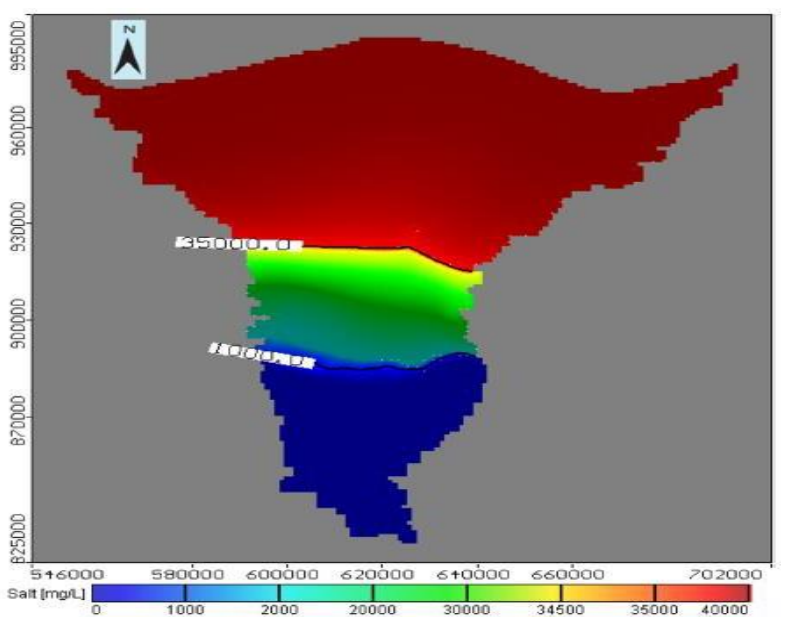

(b)

Figure 16 (a) Equipotential lines and velocity distribution in the Nile Delta...(b) Concentration distribution in the horizontal view 
Assessment of Groundwater Resources after GERD in Egypt

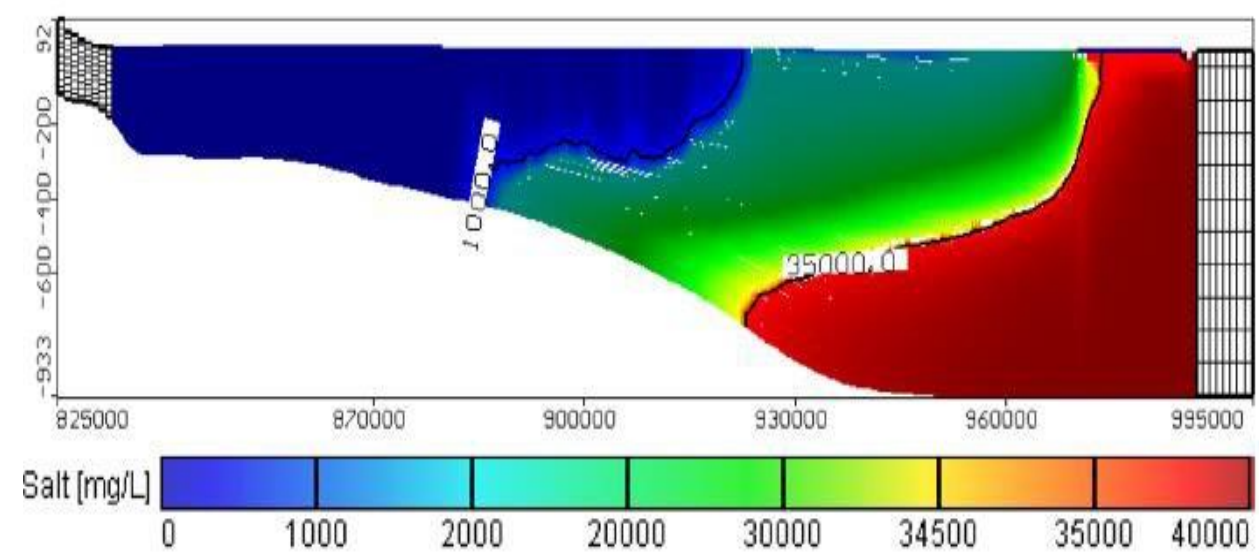

Figure 17 Salinity Distribution in vertical view, section Y-Y

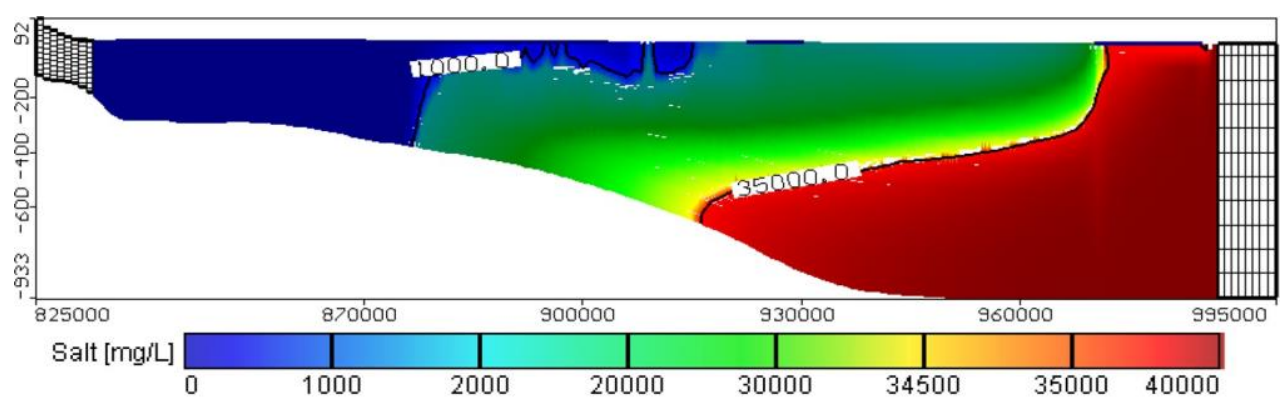

(a) Scenario one (filling the GERD reservoir in 3 years)

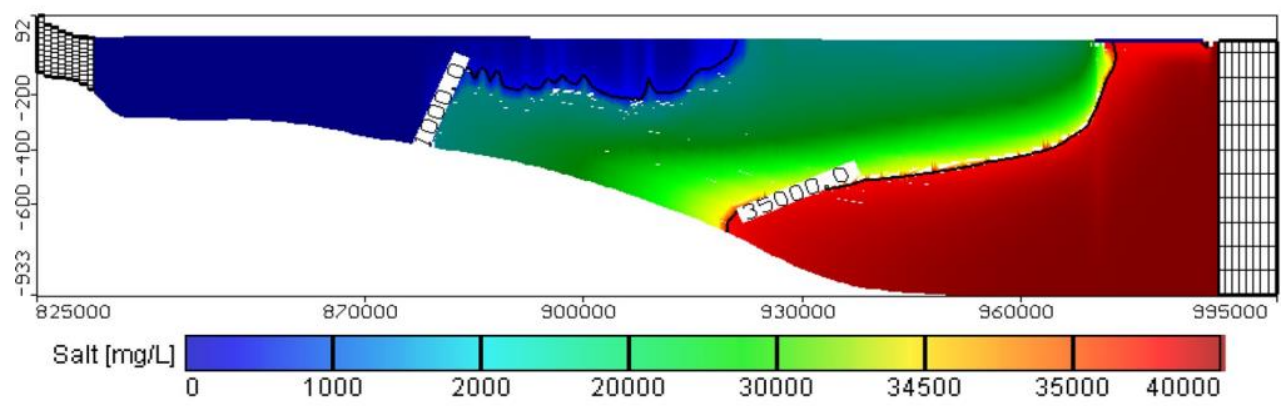

(b) Scenario two (filling the GERD reservoir in 6 years)

Figure 18 Scenario one and two (filling the GERD reservoir in 3 and 6 years)

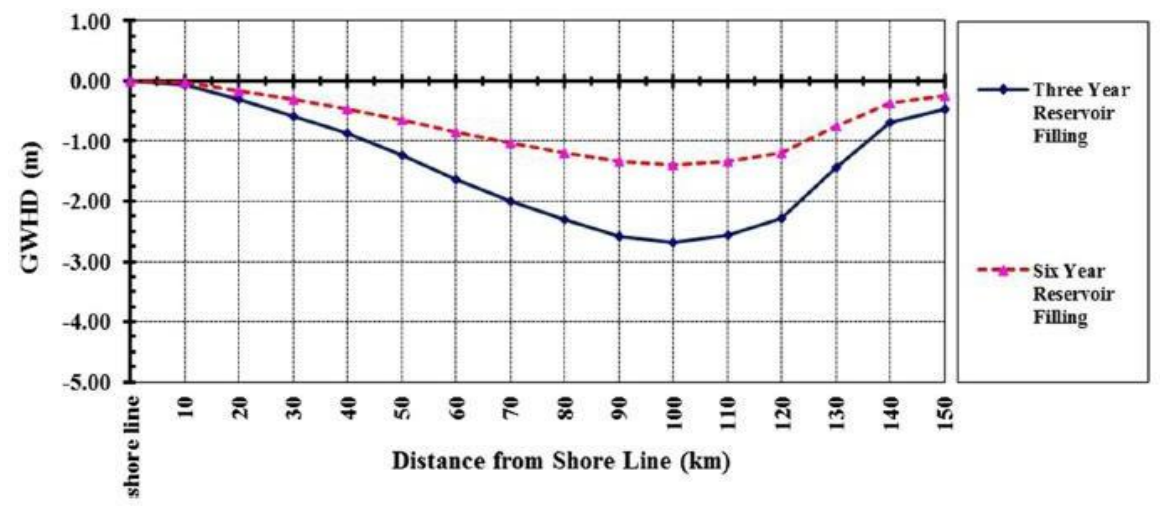

Figure 19 Decline of the groundwater in the middle Delta in different scenarios for GERD reservoir filling 
Another study was done by Armanuos et. al., 2017 to evaluate the potential impact of Grand Ethiopian Renaissance Dam (GERD) and pumping scenarios on groundwater level by a three-dimensional groundwater model of the Nile Delta using MODFLOW software, considering The Nile Delta highly intensive irrigation canal networks that share yearly about $35.5 \mathrm{~km}^{3}$ of water. Previous studies have considered groundwater recharge depending on 10 canals in groundwater modeling in spite of the actual irrigation network in Nile Delta region consisting of about 200 canals (MWRI 1954).

In this study, an integrated three-dimensional groundwater model was built considering the actual condition of the irrigation canals and their recharges of the Nile Delta aquifer. The model was calibrated for estimating the vertical and hydraulic conductivity. The model was run for three scenarios: (1) reduction of water depth in canals, (2) increasing pumping discharge from the aquifer and (3) combination between the first and second scenarios. Results reveal that the effect of increasing the pumping discharge on groundwater level in the Nile Delta is more significant than decreasing the water depth of the canals network due to the fact of the existence of the upper clay layer which reduces the amount of water penetrating and reaching the groundwater in the aquifer. Decreasing the water depth by $25 \%$ leads to drawdowns of 0.30 $\mathrm{m}, 0.5 \mathrm{~m}$ and $0.2 \mathrm{~m}$ in average in the western, central area and eastern parts of the Nile Delta while a further drawdown is expected to reach $0.6 \mathrm{~m}, 0.7 \mathrm{~m}$ and $0.4 \mathrm{~m}$ in average in case of decreasing the water depth by $50 \%$. Increasing the pumping discharges by $25 \%$ led to drawdowns of $0.35 \mathrm{~m}, 1.0 \mathrm{~m}$ and $0.5 \mathrm{~m}$ in average in the western, central area and eastern parts of the Nile Delta while a further drawdown is expected to reach $0.7 \mathrm{~m}, 1.5 \mathrm{~m}$ and $1.27 \mathrm{~m}$ in average in case of increasing the pumping discharges by $50 \%$. The last scenario presents the worst case as the average drawdown reached $1.26 \mathrm{~m}, 1.7 \mathrm{~m}$ and $1.35 \mathrm{~m}$ in the western, central and eastern parts of the Nile Delta respectively.

\section{CONCLUSIONS}

Groundwater is a valuable source in Sudan and Egypt. However, it is facing many challenges in next few decades due to climate changes, rapid population increase and development in the upper Nile Basin countries. All of these factors are putting more stresses on this source.

Groundwater rise in Sudan is one of the main problems which are expected to happen during and after filling the Grand Ethiopian Renaissance Dam (GERD) reservoir. This, in turn, can lead to rapid deterioration in quantity and quality of groundwater, especially after reduction of natural sediments and the use of artificial fertilizers. Groundwater rise will lead to less production for crops and might need for construction of costly drainage systems.

In Egypt, groundwater sector will suffer of rapid declination in levels due to the reduction of water recharge in the renewable aquifers (Nile Valley and Delta aquifers). This decline is expected due to climate change (on the long term) and due to GERD reservoir filling and operation stages (on the short term) which will cut large volumes of water which used to reach to Egypt from August to October/November. Moreover, the availability of the water all the year time and turning the flow into controlled instead of natural flow will encourage for more uses of the water in Sudan, which means more shortage in water supply to Egypt. Such decline in surface water shortage will put more pressure on the renewable and non-renewable aquifers in Egypt.

Another concern is seawater intrusion which will affect the groundwater quality. Another potential environmental impact that would result from seawater intrusion is the salinization of the lands which will adversely affect the agricultural activities and production. Moreover, it will be the cause of the loss of the fishery practiced in the brackish water lakes that fringe the coast of Egypt. Approximately 90\% of the fish consumed in Egypt are taken from these lakes, and most of the species would not tolerate significantly higher concentrations of salt. 
During the flood period, the freshwater that goes to the sea encourages salmon fish to come to the northern shores, which was a big benefit for the fishers.

A comprehensive monitoring program through observation wells is required to monitor the groundwater levels for evaluations of the quantity and quality of groundwater and its interaction with surface water of the Blue Nile. The other environmental, economic, and social effects of the GERD on the downstream countries should be investigated.

\section{RECOMMENDATIONS TO MINIMIZE THE WATER SUPPLY SHORTAGE AND TO PRESERVE THE GROUNDWATER SOURCES}

Stakeholders and water specialists in Egypt should think in many other alternatives to overcome the challenges in water sector for the next decades. As explained before, traditional water supply is vulnerable to many reasons and non-traditional sources should be well studied and planned. Many alternatives are discussed in the following sections.

\subsection{Reducing Evaporation Losses from Lake Nasser}

Water loss from the reservoir due to evaporation is between 10 and 16 billion $\mathrm{m}^{3}$ every year (Abd-El Monsef and Darwish, 2015). The wide range is because evaporation volume is a function of the surface area of Lake Nasser/Lake Nubia. Further research on ideas such as a pontoon framework and circular foam sheets is being performed. Another idea is to partially or fully disconnect some of the secondary channels (khors) that do not contribute appreciably to the storage capacity of Lake Nasser due to their shallowness but highly contribute to evaporation from the lake due to their high surface area (Elba et. al., 2014). They recommend disconnecting some of the khors based on their contribution to evaporation.

There are a considerable number of ideas and techniques to reduce the amount of water lost by evaporation from Lake Nasser water surfaces. They can be summarized as follows (Hassan et al., 2007): changing water levels upstream Aswan High Dam, cultivating special crops on the lake surface, and closure of secondary channels (khors).

Applying the technique in which all the water surface is covered is not practically acceptable as the complete coverage of the surface prevents the exchange between air and water, a matter that affects the oxygen demand needed by the aquatic ecology. Another shortcoming is the use of cover sheets with irregular shapes that lead to the overlapping of sheets when the wind speed becomes faster.

The evaporation can be reduced from an open water surface using floating cover sheets. Different geometric shapes (triangular, trapezoidal, square, irregular, circular, and rectangular) for the cover sheets were studied to find the best one, which gives the maximum percent coverage and permits oxygen exchange between air and water. The most suitable shape achieving the maximum coverage and permitting sunlight penetration through the water was the circular one. Different coverage materials were subject to experimentation and comparison as far as their ability to reduce evaporation from open water surfaces and their durability and cost are concerned. These materials were, for instance, the waxen texture sheets, polystyrene, foam, foamed rubber, perlite ore, plastic sheets, poly-laminated plastic, polystyrene beads, and polystyrene rafts. The most suitable material is the foam sheets.

In conclusions, the yearly average of the daily evaporation rate from Lake Nasser is 6.3 $\mathrm{mm} /$ day. The average volume of the annual water loss by evaporation is about 12.5 milliards cubic meter. To save more than 1 million cubic meters of water loss from Lake Nasser, 0.500 $\mathrm{km} 2$ must be covered with circular foam sheets with an efficiency of coverage equal to $90 \%$ (Hassan et al., 2007). The circular foam system can be adjusted such that it has no impact on the passage of sunlight to aquatic life. 


\subsection{Rainwater Harvesting}

Egypt is a very arid country, where the average annual rainfall seldom exceeds $200 \mathrm{~mm}$ along the northern coast. The rainfall declines very rapidly from coastal to inland areas and becomes almost nil south of Cairo. This meager rainfall occurs in the winter in the form of scattered showers and cannot be depended upon for extensive agricultural production. This amount (1 billion $\mathrm{m}^{3} /$ year) cannot be considered a reliable source of water due to its spatial and temporal variability (Ashour et al., 2009). Areas dependent on rainwater in Egypt cover nearly 2.8 million ha (6.7 million feddan). Most of these areas are located along the Egyptian north coast, between Al-Salloum in the west, near the Libyan border, and Rafah in the east, along with the border with the Palestinian territories. Rainfall can be reliably harvested and used in many countries adding some millions m3/year to the Arab water resources. Detailed records of rainfall and flash floods are needed to better estimate the amount of water and to adopt appropriate water harvesting technology. Rainfall water is discharging into the Nile River through wadis in Upper Egypt during flash flood seasons. Although this amount of water is small compared with the Nile River discharges, it is considerable in the case of heavy rain on the east and west wadis along the Nile River. In the last few years, the importance of flash flood water increased, due to the increase of population density in the major urban areas of Egypt. This has been a serious stress on the quantity and quality of water. The estimated flash flood water, which is discharging into the Nile River, can be used to control the discharged water to the Nile River from the Aswan High Dam, in order to avoid wasting water, especially in the rainy seasons. The total quantity of flash flood water which discharges into the Nile

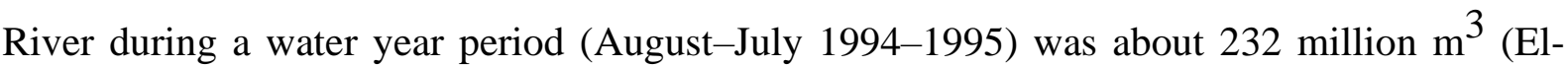
Barbary and Sallam, 2004).

The wadis located east of the Nile River contributed flash flood water (221.50 million m3) more than those located west of the Nile River (10.50 million m3). The second reach (IsnaNag Hammadi) is considered the most contributing reach of flash flood water to the Nile River $\left(142 \mathrm{~m} \mathrm{~m}^{3}\right)$, followed by the third $\left(56 \mathrm{~m} \mathrm{~m}^{3}\right)$ and fourth $\left(23 \mathrm{~m} \mathrm{~m}^{3}\right)$ reaches, while the first reach is the least contributor $(11 \mathrm{~m} \mathrm{~m} 3)$. October $(129.90 \mathrm{~m} \mathrm{~m} 3)$, November $(74.95 \mathrm{~m}$ $\mathrm{m} 3)$, March (10.59 m m3), September (9.35 m m3), and February $(6.84 \mathrm{~m} \mathrm{~m} 3)$ are the months of maximum flash flood water, respectively (El-Barbary and Sallam, 2004).

\subsection{Seawater Desalination}

New water sources are rarely available in Egypt for irrigation. It is even less likely for this to be provided to potential users in the future for little or no cost. The use of nonconventional water sources has been practiced for a long time in Egypt. An additional option is desalinization, which is being applied in several areas (some coastal towns, islands, remote industrial sites). The desalination capacity in Egypt has grown to some 150,000 $\mathrm{m} 3$ day_1 (Abd El Moniem, 2009). The water desalination process separates dissolved salts and other minerals from water. Feed water sources may include brackish, seawater, well, surface water (rivers and streams), wastewater, and industrial feed and process waters. There are two major types of desalination technologies around the world, namely, membrane desalination and thermal desalination. The former technology features the use of a special filter (membrane) to produce desalinated water, whereas the latter technique involves the boiling/evaporation of seawater to give off water vapor, which, on condensation, yields salt-free liquid water.

Nonconventional systems are existing in numerous locations in Egypt, but only for smallscale applications. It is now feasible, technically and economically, to produce large quantities of water of excellent quality from desalination processes. 
The cost of desalinated seawater is decreasing. Desalination of brackish water is even cheaper. Many countries are now considering desalination as an important source of water supply (Batisha, 2007).

\subsection{Sewage Treatment and Reusing Irrigation Water}

Treatment and reuse of sewage waters are becoming a common source of additional water in some water-scarce regions. Reuse of wastewater may contribute to future water availability than any other means of water supplies. Water recycling and reuse provide a unique and a viable opportunity to increase traditional water supply. Water reuse can help to close the loop between water supply and wastewater disposal. Firstly, properly treated municipal wastewater often is a significant water resource that can be utilized for a number of beneficial purposes, such as agricultural and landscape irrigation. Secondly, discharge of sewage effluent into surface water is challenging and costly as treatment requirements become more severe to protect receiving waters such as rivers, estuaries, and beaches. The volume of drainage water reused for irrigation has planned to reach a value of $8.3 \mathrm{BCM} / \mathrm{year}$ by the year 2017 . The reuse of domestic and industrial wastewater is estimated to reach about $1.5 \mathrm{BCM} / \mathrm{year}$ by the year 2025 (Rassoul, 2006).

In addition, reuse of sewage waters, when properly managed, has the advantage of reducing environmental degradation. Water treatment requires chemical, physical, and biological processes to remove contamination. The more common processes used in potable water treatment are the chemical and physical processes. Biological processes are primarily used for the treatment of wastewater. Bioremediation is contamination control innovation that utilizes characteristic biota (microscopic organisms and parasites) and their procedures for contamination diminishing. It is a safe and practical process. Organisms can expel heavy metals from polluted water.

This process is referred to as bioaccumulation or as biosorption with ease and in an ecofriendly way. The technique utilizes inherent biological mechanisms to eradicate hazardous contaminants using microorganisms and plants, or their products, to restore polluted environments to their original condition (Mani, 2014). It is an environmentally friendly and cost-effective technique for heavy metal removal/recovery, when compared to the conventional chemical and physical techniques, which is often more expensive and ineffective, especially for low metal concentrations.

\subsection{Maximizing Water Use Efficiency}

Different factors recommended maximizing the water use efficiency. First, improve the surface irrigation system by converting small field canals from the surface canal to pipes. This will save $42 \%$ of water losses due to seepage and evaporation (El-Nashar and Elyamany, 2017). Second, utilize fixed furrow irrigation system to save more than $35 \%$ from water applied which is equal to $\mathrm{m}^{3} / \mathrm{m}^{2}$ (Said, 1993). Then the saved water is 9.36 BCM. Third, decrease irrigation losses by using modern irrigation systems such as sprinkler and drip irrigation in newly cultivated land. The efficiency of modern irrigation systems is $75-85 \%$, in average $80 \%$. Fourth, modify the cropping pattern by using low consumptive use crops. Eliminating rice and other water-consuming plants from the crop pattern could save Egypt nearly one BCM of water, annually (NRI, 2016). One of the strategies which must be used to maximize water efficiency is the establishment of agricultural projects with Nile Basin countries. The establishment of agricultural projects with Nile Basin countries, such as rice cultivation in countries with abundant water, will maximize the water use in Egypt. 


\section{REFERENCES}

[1] Abd El Moniem A (2009) "Overview of water resources and requirements in Egypt; the factors controlling its management and development". J Environ Stud 2:85-97.

[2] Abd-El Monsef H, Smith S, Darwish K (2015) "Impacts of the Aswan High Dam after 50 years", Water Resour Manag 29:1873-1885. https://doi.org/10.1007/s11269-015-0916-z

[3] Abdelhaleem F, Helal E (2015) "Impacts of Grand Ethiopian Renaissance Dam on different water usages in Upper Egypt", Br J Appl Sci Technol 8(5):461-483.

[4] Abd-Elhamid, H., Abdelaty, I. \& Sherif, M. (2019) "Evaluation of potential impact of Grand Ethiopian Renaissance Dam on Seawater Intrusion in the Nile Delta Aquifer". Int. J. Environ. Sci. Technol. 16, 2321-2332. https://doi.org/10.1007/s13762-018-1851-3

[5] Abtew W., Dessu S.B. (2019) "Grand Ethiopian Renaissance Dam Analysis. In: The Grand Ethiopian Renaissance Dam on the Blue Nile. Springer Geography. Springer, Cham. https://doi.org/10.1007/978-3-319-97094-3_6

[6] Abu Zeid, M., Rady, M. (1992) "Water resources management and policies in Egypt. In: country experiences with water resources management: economic, technical sand environmental issues", World Bank, Technical paper no. 175, Washington DC.

[7] Allam, R., Saaf. E., Dawoud, M., (2002) "Desalination of brackish groundwater in Egypt". Desalination 152, Elsevier, pp 19-26.

[8] Ambroggi, R. (1966) "Water under the Sahara". Sci Am 214:21-29.

[9] Armanuos A., Ibrahim M., Wael E., Negm A., Yoshimura C., Takemura J., and Zidan B. (2017), "Evaluation of the potential impact of Grand Ethiopian Renaissance Dam and pumping scenarios on groundwater level in the Nile Delta aquifer", Water Supply, Volume 17, Issue 5 .

[10] Ashour M, El Attar S, Rafaat Y, Mohamed M (2009) "Water resources management in Egypt”, J. Eng Sci Assiut Univ 37(2):269-279.

[11] Aziz, S.A., Zeleňáková, M., Mésároš, P., Purcz, P., Abd-Elhamid, H. (2019) “Assessing the Potential Impacts of the Grand Ethiopian Renaissance Dam on Water Resources and Soil Salinity in the Nile Delta, Egypt", Sustainability, 11, 7050.

[12] Bakheit H (2013) "Millennium dam: a report on the Ethiopian millennium dam, its impact on Sudan". Sudanow Magazine, Khartoum. http://news.sudanvisiondaily.com/details.html?rsnpid1/4223142.

[13] Bates A, Tuncok K, Barbour T, Klimpt JE' (2013) First joint multipurpose program identification: strategic perspectives and options assessment on the Blue Nile multipurpose development - working paper 2. Author Report to Nile Basin Initiative, Addis Ababa

[14] Batisha A (2007) "Water desalination industry in Egypt", Eleventh international water technology conference, IWTC11 2007, Sharm El- Sheikh.

[15] Beyene, A. (2013) "Reflections on the Grand Ethiopian Renaissance Dam", Retrieved April 2, 2016, http://www.opride.com/oromsis/news/horn-of-africa/3664-reflections-on- thegrand-ethiopian-renaissance-dam

[16] Chen H, Swain A (2014) "The grand Ethiopian Renaissance Dam: evaluating Its sustainability standard and geopolitical significance". Energy Dev Front 3(1):11.

[17] Consulate General of Ethiopia (CGE) (2013) "Grand Ethiopian renaissance dam". http://www.ethiopianconsla.org/Documents/BONDINFORMATIO N.pdf

[18] Eckstein, Y, Eckstein, G (2005) Transboundary Aquifers: conceptual models for development of international law. Ground Water. Vol. 43(5): 679-690.

[19] Egyptian Chronicles. (2013) "Group of the Nile Basin: Cairo University's report on Ethiopia's Great Renaissance Dam”, Retrieved April 2, 2016, from http://egyptianchronicles.blogspot.com/2013/06/cairo-universitys- report-on-ethiopias.html 
[20] El Bastawesy, M., Gabr, S., Mohamed I. (2015) "Assessment of hydrological changes in the Nile River due to the construction of Renaissance Dam in Ethiopia”, The Egyptian Journal of Remote Sensing and Space Sciences 18, 65-75.

[21] El Tahlawi, M.R., Farrag, A.A. \& Ahmed, S.S. (2008) "Groundwater of Egypt: an environmental overview". Environ Geol 55, 639-652. https://doi.org/10.1007/s00254-0071014-1

[22] Elba E, Farghaly D, Urban B (2014) "Modeling high Aswan Dam reservoir morphology using remote sensing to reduce evaporation", Int J Geosci 5:156-169.

[23] El-Barbary Z, Sallam G (2004) "Optimizing use of rainfall water in East Desert of Egypt", Eighth international water technology conference, IWTC8 2004, Alexandria.

[24] El-Nashar W, Elyamany A (2017) "Managing risks of the Grand Ethiopian Renaissance Dam on Egypt", Ain Shams Eng J.

https://doi.org/10.1016/j.asej.2017.06.004

[25] Ethiopian NPoE. (2013) "Unwarranted anxiety. The Grand Ethiopian Renaissance Dam (GERD) and some Egyptian experts hyperbole". Retrieved: April, 2016. http://www.mowr.gov.et/index.php?pagenum $=0.1 \&$ ContentID $=88$

[26] Farrag, A.A. (2005) "The hydraulic and hydrochemical impacts of the Nile system on the groundwater in upper Egypt", Assuit Univ. Bull. Environ. Resources, 8, 87-102.

[27] Gebreluel G (2014) “Ethiopia's Grand Renaissance Dam: ending Africa's oldest geopolitical rivalry?" Wash Q 37(2):25-37.

[28] Garstin W (1904) "Report upon the basin of the upper Nile with proposals for the improvement of that river". National Printing Department, Cairo.

[29] Hammond M (2013) "The Grand Ethiopian renaissance dam and the Blue Nile: implications for transboundary water governance GWF Discussion", Paper 1307, Global Water Forum, Canberra, Australia. http://www.globalwaterforum.org/wp-content/uploads/2013/02/TheGrand-Ethiopian-Renaissance-Dam-and-the-Blue-Nile-Implications-for- transboundary-watergovernance-GWF-1307.pdf.

[30] Hassan R, Hekal N, Mansor N (2007) "Evaporation reduction from Lake Nasser using new environmentally safe techniques", Eleventh international water technology conference, IWTC11 2007, Sharm El- Sheikh.

[31] Hefny, K. (1992) "Groundwater assessment in Egypt", International Water Resources Association Magazine, Oxford.

[32] Keith B, Epp K, Houghton M, Lee J, Mayville R (2014) "Water as a conflict driver: estimating the effects of climate change and hydroelectric dam diversion on the Nile River stream flow during the 21 st century", Center for Nation Reconstruction and Capacity Development. United States Military Academy, West Point, New York.

[33] Kevin G., Mohammed B., Zelalem T., Sami O., Azeb Mersha, Gamal M., Edith A., Jim W. and Simon J. (2016) "Cooperative filling approaches for the Grand Ethiopian Renaissance Dam”, Water International, 41:4, 611- 634, DOI: 10.1080/02508060.2016.1177698.

[34] Klitzsch, E., Wycisk, P. (1999) "Beckenentwicklung und

Sedimentationsprozesse in Kratonalen Bereichen Nordost-Afrikas im Phanerozoikum". In Klitzsch, E, Thorweihe, U (eds). Nordost-Afrika: Strukturen und Ressourcen, John Wiley \& Sons-VCH, Weinheim, pp 61- 108.

[35] Mani D, Kumar C (2014) "Biotechnological advances in bioremediation of heavy metals contaminated ecosystems: an overview with special reference to phytoremediation", Int $\mathrm{J}$ Environ Sci Technol 11:843-872.

[36] Margat, J, Foster, S, Droubi, A (2006) "Concept and importance of non- renewable resources", IHP-V, Technical Documents in Hydrogeology, 42: 13-24. UNESCO, Paris.

[37] MIT. (2014) "The Grand Ethiopian Renaissance Dam: An opportunity for collaboration and shared benefits in the Eastern Nile Basin: An amicus brief to the Riparian Nations of Ethiopia, 
Sudan and Egypt from the international, non-partisan Eastern Nile working group", Boston: Massachusetts Institute of Technology.

[38] Mohamed M, Elmahdy S (2017) "Remote sensing of the Grand Ethiopian Renaissance Dam: a hazard and environmental impacts assessment", Geomat Nat Haz Risk. https://doi.org/10.1080/19475705.2017.1309463

[39] Mulat AG, Moges SA (2014) "Assessment of the impact of the Grand Ethiopian Renaissance Dam on the performance of the High Aswan Dam", J Water Resources, 6(6):583.

[40] MWRI (1954) "Irrigation and drainage network Nile Delta map", Scale 1:200,000. Prepared by Ministry of Water Resources and Irrigation.

[41] NRI (2016) "Annual reports from 2000 to 2006 Lake Nasser hydrology measurements in 1964 to 2008", Technical report by Nile Research Institute, Cairo.

[42] Ramadan SM, Negm AM, El-Smanny M, El-sayed AH (2015) Quantifying the impacts of impounding Grand Ethiopian Renaissance Dam Reservoir on Nasser Lake active storage. In: Proceedings of eighteenth international water technology conference (IWTC 18), Sharm ElSheikh, 12-14 March, Egypt.

[43] Rassoul A (2006) "Prospects of water reuse in Egypt", Tenth international water technology conference, IWTC10 2006, Alexandria, pp 561-567.

[44] RIGW/IWACO “Research institute for groundwater" (1988, 1993) Hydrogeological map of Egypt, scale 1:2,000,000. Cairo.Said R (1993) "The River Nile; geology, hydrology and utilization", Pergamon Press, Oxford.

[45] Said R (1993) “The River Nile; geology, hydrology and utilization”, Pergamon Press, Oxford.

[46] Salem, O, Pallas, P (2004) “The Nubian Sandstone Aquifer System”, In Appelgren, B (ed). Managing Shared Aquifer Resources in Africa. ISARM-AFRICA. UNESCO, IHP-VI, Series on Groundwater No. 8: 19- 21.

[47] Taye MT, Tadesse T, Senay GB, Block P (2016) "The grand Ethiopian Renaissance Dam: source of cooperation or contention?” J Water Resour Plan Manag 142(11):02516001.

[48] Thorweihe, U., Heinl, M. (2002) "Groundwater resources of the Nubian Aquifer System, NE Africa”, Modified synthesis submitted to Observatiore du Sahara et du Sahel (OSS, Paris).

[49] US Bureau of Reclamation (1964) "Land and water resources of the Blue Nile basin: Ethiopia", main report and appendices I-V. Government Printing Office, US Department of Interior, Washington.

[50] Werwer AM, Mahmoud ME, Esmail AH (2000) "Groundwater quality of east El-Oweinat (Western Desert, Egypt)", The first international conference for environmental hazards mitigation (ICEHM2000) Abstracts, Cairo University, Giza.

[51] Wheeler K, Basheer M, Mekonnen Z, Eltoum S, Mersha A, Abdo G, Zagona E, Hall J, Dadson S (2016) "Cooperative filling approaches for the Grand Ethiopian Renaissance Dam". Water Int 41(4):611-634. https://doi.org/10.1080/02508060.2016.1177698

[52] Williams MAJ. (2009) Late Pleistocene and Holocene environments in the Nile basin. Global and Planetary Change 69: $1-15$. 